\title{
Museum Representations of Roman Britain and Roman London: A Post-colonial Perspective
}

\author{
By MARTIJN POLM
}

\begin{abstract}
This paper offers a post-colonial analysis of past and present representations of the archaeological remains of Roman Britain and Roman London in the British Museum and Museum of London respectively. Since post-colonial criticism of Romano-British archaeology is highly relevant to such an analysis, a brief description is provided at the outset. Thereafter follows a series of six case studies - three for each museum. The first four focus on the history of the Romano-British collections at both museums and sometimes draw on postcolonial insights to explain the development of these collections and the ways in which they were exhibited. The last two case studies investigate how British post-colonial criticism of Roman archaeology has (or has not) impacted on the current displays of the Romano-British collections at both museums. Finally, some recommendations will be offered based on the outcomes of these two case studies. Recurring themes are the representation of: the Roman military; Roman imperialism; the (material) culture of Roman Britain and Roman London.
\end{abstract}

Keywords: Roman Britain; Roman London; The British Museum; The Museum of London; museum archaeology; post-colonialism; museum representations

\section{INTRODUCTION: POST-COLONIAL CRITICISM OF ROMANO-BRITISH ARCHAEOLOGY}

B ritish post-colonial criticism of Roman archaeology is primarily aimed at correcting a Romano-centric focus in research agendas, which arose out of a late Victorian and Edwardian fascination with everything Roman, itself a product of the contemporary impact of British imperialism, which some considered similar to Roman imperialism. This Romano-centric focus led to a Roman/élite research bias, since most archaeological work was concentrated on excavating 'Roman' categories of site such as cities, towns, forts, frontier works, roads and villas. ${ }^{1}$ This bias has caused a major imbalance in research results, since excavations of military sites, major towns and villas comprised over half of the sites excavated,

$1 \quad$ Hingley 2000, 149-52. 
while over 95 per cent of all Roman period sites are thought to have been non-villa rural settlements. $^{2}$

Due to the impact of post-colonial criticism the number of excavated non-villa rural settlements has increased from the late 1960s onward. Nevertheless, there still exists a major imbalance in research efforts, with relatively few excavations being aimed at unearthing non-villa rural settlements. ${ }^{3}$ Commercial archaeology, in particular, has made a significant contribution to the increase in excavations of non-villa rural settlements, which is encouraging since it constitutes more than three quarters of all archaeological investigations in England (rescue archaeology made up 89 per cent of all archaeological investigations in England between 1990 and 2000). Even so, it should be noted that this does not necessarily reflect a major shift in research priorities, as the locations of these planning process investigations are not determined by academic research agendas, but by contemporary economic concerns on the part of developers, local authorities and the national government. Work by local archaeological societies, for instance, is still mostly focused on traditional 'Roman' categories of site, such as villas. ${ }^{4}$

Apart from the desired shift in the categories of site which are excavated, archaeologists have also come up with a number of theoretical solutions to the Romano-centric bias in Romano-British archaeology. These solutions have mainly drawn on two, related, bodies of theory - post-colonial theory and globalisation theory. Post-colonial theory, as the name suggests, finds its origin in the re-evaluation of more recent Western imperialisms after the dissolution of the European world empires in the aftermath of the Second World War. Just as it has led scholars who specialise in the history of more recent European empires to challenge the Eurocentric bias within historical accounts and other representations of this period in Western history, it has led Roman archaeologists to challenge the Romano-centric bias within narratives about the Roman Empire and its provinces. The influence of post-colonial theory can be said to have brought about the end of the idea, propagated by Haverfield's Romanisation theory, that Roman imperialism led to cultural homogeneity in the provinces. Instead, local diversity and the existence of cultural hybridity are emphasised. These two themes are also central to the second body of theory which has been used to dispense with the model of cultural change offered by Romanisation globalisation theory. ${ }^{5}$

Several studies have drawn upon these two bodies of theory either to re-evaluate existing scholarship on Roman Britain, or to offer an alternative reading of its history. David Mattingly's monograph An Imperial Possession: Britain in the Roman Empire, 54 BC-AD 409, for example, is a deliberate attempt to provide a stark contrast to prevailing narratives about Roman Britain, which usually present Roman rule in Britain in predominantly positive terms. ${ }^{6}$ Richard Hingley's monograph Roman Officers and English Gentlemen: The Imperial Origins of Roman Archaeology is of a different nature and attempts to elucidate how comparisons drawn between the Roman and British Empires in the late nineteenth and early twentieth century influenced both written narratives about Roman Britain and the early development of RomanoBritish archaeology. ${ }^{7}$ As far as the author knows, however, there have been no attempts to analyse how these comparisons, which highlighted supposed similarities between the Roman and British Empires, impacted on late nineteenth-century and early twentieth-century museum representations of Roman Britain; nor has there been a detailed exploration of the impact which post-colonial criticism of Romano-British archaeology has had on contemporary representations

Mattingly 2007, 46.

Hingley 2000, 150; Mattingly 2007, 46.

Fulford and Holbrook 2011, 323-7, 330, 332.

For a brief but comprehensive analysis of the impact of post-colonial theory and globalisation theory see Gardner 2013, 3-9.

6 Mattingly 2007, 1-20; 2014, 274-5.

7 Hingley 2000, xii-xiii. 
of Roman Britain. ${ }^{8}$ This paper attempts to do both by analysing the representation of Roman Britain and Roman London in the British Museum and the Museum of London (and its two predecessors) respectively, from the nineteenth century onwards. Since museum displays reach more - as well as a wider range of - people than written archaeological accounts of Roman Britain, it is especially important to study these museum representations - representations which can arguably be described as the public face of Roman archaeology.

\section{MUSEUM REPRESENTATIONS OF ROMAN BRITAIN AND ROMAN LONDON}

\section{THE ORIGINS OF THE ROMANO-BRITISH COLLECTIONS IN THE BRITISH MUSEUM}

The British Museum was created in 1753 to house the collections of the late Sir Hans Sloane (1660-1753), a physician and scientist who, over the years, had accumulated a large collection which was mainly focused on natural history. In addition, Sloane had also collected a variety of man-made objects — which were long called 'artificial productions' in the British Museum. ${ }^{9}$ The division between naturalia and artificialia was an old one and found its origin in the so-called Kunst- und Wunderkammer; these were cabinets of curiosities, the first of which were founded during the mid-sixteenth century in — as the name suggests - German-speaking central Europe. ${ }^{10}$ Among the artificial productions in Sloane's collections there were few provincial Roman antiquities - about two dozen in a total of $c$. 71,000 objects which he had bequeathed to the nation ${ }^{11}$ _ or classical Roman antiquities for that matter. ${ }^{12}$ Sloane seems to have considered the Roman antiquities in his collection to be of little interest. ${ }^{13}$ The museum's first Trustees appear to have shared this opinion, for it was not until 1772 that they would spend money on the acquisition of classical antiquities. This first purchase of a collection of classical antiquities, which mainly consisted of Greek vases found in Southern Italy, ensured that, from that moment on, the museum's focus would not just be on natural history, but also on the display of classical antiquities. Change came slowly, however, and it was not until 1807 that the Trustees resolved to separate the museum's collections of antiquities from the Department of Natural History. In this year the Department of Antiquities was created, a department which would form the basis of the present British Museum. ${ }^{14}$

The death of Charles Townley (1737-1805), one of the museum's Trustees and a collector of classical sculpture, led to a second major acquisition of classical antiquities in 1805 - the purchase of his collection of Roman statues, ${ }^{15}$ which ensured that the museum now owned one of the largest collections of Roman copies of Greek originals. ${ }^{16}$ This was displayed in a new wing of the museum (aptly called the Townley Gallery), which also held Roman antiquities from Britain. ${ }^{17}$ It has been suggested that the antiquities displayed in the Townley Gallery were

\footnotetext{
8 Francis Grew has done so, however, with regard to the representation of Roman London in the Tower Hill Pageant (a 'dark ride' and museum which was open in London between 1991 and 1997) and in the Roman gallery of the Museum of London between 1996 and 2000, see Grew 2000 and 2001. In addition, Nancy Netzer has written a paper about the representation of Romano-British art in the British Museum which incorporates elements of post-colonial theory, see Netzer 2014.

Wilson 2002, 11-21, especially 15.

10 Scheicher 2005, 15.

11 Netzer 2014, 195.

12 Wilson 2002, 16.

13 Jenkins 1994, 167.

14 Wilson 2002, 32-3, 46-7, 60.

15 Wilson 2002, 60, 64-6.

16 Dyson 2006, 136.

17 Wilson 2002, 64, 66-7.
} 
meant to highlight Britain's global power by hinting at the existence of parallels with the Roman Empire, ${ }^{18}$ a suggestion perhaps strengthened by the fact that, from the Revolution of 1688 (which circumscribed the powers and privileges held by the monarchy) onward, the British aristocracy and the gentry identified themselves with the senatorial oligarchy of the Roman Republic and the classical principles of liberty and civic virtue which were associated with it; ${ }^{19}$ in addition, Roman architecture, art and literature were widely admired among members of Britain's eighteenth-century social élite. ${ }^{20}$ It is, however, unlikely that the display presented a significant degree of similarity between the post-Republican Roman Empire and the British Empire since imperial Rome was, at that time, perceived in mainly negative terms. This negative image of Rome as a despotic, corrupt and decadent empire, would last until the late 1870s, when following the controversial 1876 Royal Titles Act, which allowed Queen Victoria to take the title 'Empress of India' - imperial Rome began to be interpreted in a more positive fashion. Before then, Hellenic images dominated any parallels which were drawn between classical antiquity and the present. ${ }^{21}$ The preference for Greek models was one reason why Charles Newton (1816-94), a British classicist and archaeologist who would be Keeper of Greek and Roman Antiquities from 1861 to 1888 , was able to obtain the funds necessary from Parliament to expand the museum's Greek sculpture collection, making it the largest and most representative collection of Greek originals in the world. ${ }^{22}$

In early 1827, the numismatist Edward Hawkins (1780-1867) was appointed as Keeper of Antiquities. Although the museum already had one of the world's largest collections of classical antiquities, there had been no co-ordinated efforts to acquire more British antiquities. Inspired by the collections of national antiquities in Edinburgh and Copenhagen, Hawkins set out to change this in a memorandum which urged the Trustees to engage in a more active collecting policy for British antiquities. This was a timely appeal, for interest in British antiquities had been on the rise for some time - bolstered by the work of the Society of Antiquaries of London and by the rise of several county archaeological societies in the 1830s and 40s. Despite Hawkins' call to collect more British antiquities, the majority of and the most substantial acquisitions made during the 1830s and 40s were classical and Egyptian antiquities. The museum was, however, able to acquire some British material through the Treasure Trove legislation, which determined that all precious metal finds should go to the Crown. Some of this material was eventually gifted to the museum or, more often, bought from the Treasury for its full market value. ${ }^{23}$

Hawkins' call for a more coherent policy with regard to the collection of national antiquities was finally answered by a Royal Commission in 1850, which recommended to Government that money should more frequently be provided for such purposes. In 1851, the wealthy antiquarian Augustus Wollaston Franks (1826-97) was appointed as assistant in the Department of Antiquities. In line with the Commission's recommendations and Hawkins' views, Franks' brief was to oversee the collection of British antiquities and the development of a gallery of national antiquities. Although he was mainly interested in collecting medieval material, he would generally stick to this remit. To this end, he arranged a new display of material in a room specifically provided for the purpose — the British and Mediaeval Room. ${ }^{24}$ This was located on the upper floor of Smirke's new British Museum building in a room which now

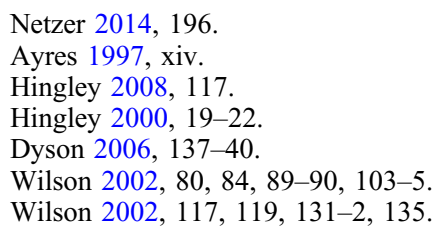


houses a display about 'Greek and Roman Life' (Room 69). ${ }^{25}$ Franks had only limited material at his disposal even after he had scoured the museum's basements in search of British antiquities, which had been stored there because they had not previously been deemed interesting enough to display. The collection which was initially exhibited in the British and Mediaeval Room, therefore, represented a far from complete or coherent overview of the period. ${ }^{26}$ Hawkins was well aware of this problem, writing in 1851 that: 'Isolated objects are of little value; a collection may accumulate a number of amusing and elegant specimens, but it is only by combination, concentration and comparison that an entertaining collection can be converted into an instructive museum and Archaeology erected into a science.'27 The same sentiment was echoed in a handbook of the museum's antiquities written by an assistant in the Department of Antiquities, who noted that: 'the only collections omitted are those by the names of British or Anglo-Roman Antiquities (...) being as yet too insufficiently arranged to admit of classification and description.' 28

Although both Hawkins and Franks were eager to follow the recommendations of the Royal Commission concerning a more active and coherent acquisition policy for British antiquities, the Trustees - convinced that the future of the Department of Antiquities lay with objects from the classical world - were much less enthusiastic. The fact that British archaeology was poorly regarded at the time did not help. In a review of a monograph about Roman Cirencester, published in 1850, the anonymous author (though it has been suggested that it was Franks) criticises the prevalent view that the remains of Roman material culture found in Britain are inferior to those found on the Continent 'in countries nearer to the seat of empire'. ${ }^{29}$ This image of Roman Britain as an obscure and remote colony of Rome and a cultural backwater was one reason why British archaeology was absent from the Great Exhibition of 1851 at the Crystal Palace. ${ }^{30}$ Unsurprisingly, therefore, the Trustees initially refused to provide the funds required for the acquisition of Charles Roach Smith's collection of antiquities. Roach Smith (1807-90) was a pharmacist, antiquarian and amateur archaeologist who, over the years, had assembled an impressive collection of Roman and medieval antiquities found in London during building and sewage works. Only after being pressurised by several national and local archaeological societies did the Trustees reconsider and request the necessary funds from the Treasury - which were granted in accordance with the recommendations set out in the 1850 Royal Commission report — to buy Roach Smith's collection in 1856. This collection of antiquities from Roman London was a very valuable addition to the museum's previously limited collection of national and, in particular, Romano-British antiquities, ${ }^{31}$ and would henceforth form the core of the British Museum's collection of national antiquities.

Collected over a period of 20 years and numbering c. 5,000 objects when he sold it to the British Museum, Roach Smith's collection was distinct from other collections previously procured because it contained a significant number of objects used in people's everyday lives, as well as objects which rarely otherwise survived because they were made of perishable material, such as leather sandals. ${ }^{32}$ Roach Smith's focus on local archaeological finds instead of

25 For a floor plan of the British Museum see The British Museum, 'Floor plans and galleries'.

26 Wilson 2002, 132

27 Hawkins 1854, 130. As cited in Potter 1997, 130.

Vaux 1851, iv.

Potter 1997, 132.

Potter 1997, 130. It should be noted, however, that, during the early $1850 \mathrm{~s}$, there was admiration for some of the Roman remains found in Britain. Hadrian's Wall in particular received praise as an impressive feat of military engineering. Nevertheless, the focus on - the highly visible - Roman military monuments in northern England probably only reinforced the image of Roman Britain as a remote military outpost, see Hingley 2008, 307-11.

31 Wilson 2002, 133-4

32 Potter 1997, 133. 
expensive marble sculptures from the Mediterranean was in part due to financial constraints. Rich aristocratic landowners were able to buy expensive marble statues during their visit to Italy as part of the Grand Tour, eager to build an impressive collection which was supposed to equal the resplendence of those of their classical 'antecedents'. ${ }^{33}$ Some landowners would go even further and use villa excavations on their own estates to draw a direct line between themselves and their Roman 'ancestors'. ${ }^{34}$ Men who were less wealthy were, however, unable to do either and, still eager to engage in the fashionable collection of antiquities, were forced to turn their attention to gathering local archaeological finds. These finds inevitably revealed much more about the daily lives of people in Roman Britain than marble sculptures could ever do. ${ }^{35}$ Roach Smith's interest in Romano-British remains may also have been strengthened by the fact that they were seen as evidence for the introduction of classical culture - much admired by Britain's social élite - to Britain. Thus, the presence of Roman antiquities was used to underpin claims that modern Britons were improving the classical culture which had once been introduced into Britain by the ancient Romans. ${ }^{36}$

After Hawkins' retirement in 1860, the oversized Department of Antiquities was split into several smaller departments. The collections of British and Mediaeval Antiquities were, however, denied a separate department, probably because - in addition to the Trustees' lack of sympathy for the collections of national antiquities - Franks was deemed too young to head a fully-fledged department (he was 34 years old then, which speaks volumes about the average age of the museum's keepers at the time). In 1866, Franks finally succeeded in persuading the Trustees to create a fourth antiquities department - the Department of British and Mediaeval Antiquities and Ethnography. Roach Smith's collection formed the core of the Romano-British collections for this department. During his tenure as keeper, Franks would continue to expand these collections by buying objects found, for example, on Hadrian's Wall and at the hillfort on Hod Hill. In addition, Franks had a personal interest in Romano-British bronzes and would donate several to the museum from his own private collection. He retired from his post in 1896 , just one year before his death in 1897. His will bequeathed an enormous number of objects from his private collections to the museum, covering all periods and regions of the world. ${ }^{37}$ As early as 1867, Franks had already received recognition for his efforts to create a complete and coherent collection of national antiquities, for he was asked to arrange to lend some of them for exhibition at the Exposition Universelle in Paris. This must have been a welcome acknowledgement of the collection's growing importance, especially since it had been ignored (like the rest of British archaeology) 16 years earlier by the organisers of the Great Exhibition of $1851 .^{38}$

From the point of view of education - surely one of the most important functions of a museum - it has been noted that Franks concentrated so much of his time on the acquisition of new objects and on scholarship that he failed to make his galleries readily accessible to the general public. The detail on the labels which accompanied the displayed objects and the information about the Romano-British antiquities in the published guidebooks was uninformative and terse in the extreme. In Franks' defence, however, it should be noted that this was not just a problem in the galleries curated by him, for throughout the museum labels were generally not very informative. ${ }^{39}$

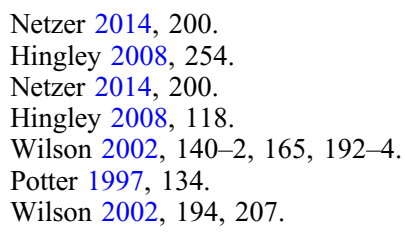




\section{The representation of the (material) culture of Roman Britain}

Until 1856, the museum published a printed guidebook, which was regularly updated. In 1859, this was replaced by the Guide to the Exhibition Rooms of the Departments of Natural History and Antiquities, which was priced at sixpence (c. £2 in today's money). ${ }^{40}$ This edition also contained a brief overview of the contents of the British and Mediaeval Room, written by Hawkins. ${ }^{41}$ Franks was responsible for the same section in the 1869,1871 and 1877 editions, ${ }^{42}$ though the information which it contained left much to be desired. The few changes which he made over the years were revisions to Hawkins' very brief description of the displayed Romano-British antiquities, made whenever new objects entered the collection. The introduction to the section about 'Roman Antiquities found in Britain', for example, would remain unchanged between 1859 and 1877:

These differ little from the Roman remains found in other countries. Some of them were no doubt imported, but the greater part must have been made in some of the flourishing cities founded by the Romans, who were more or less masters of this country for upwards of 400 years. ${ }^{43}$

Although very brief, this introduction offers a valuable insight into how both Hawkins and Franks thought about the spread of Roman (material) culture. While not excluding the possibility that some of the objects were imported, they maintain that the majority were made in Roman Britain and differed little from those made in other parts of the Empire. In addition, the text suggests that the Roman conquerors actively engaged in the building of Roman-style cities. The archaeologist Francis Haverfield (1860-1919) would later voice a comparable belief in his theory of Romanisation, which he defined as a one-way process, with conquered peoples (particularly in the western parts of Rome's empire) adopting elements of Roman culture while the Romans did not adopt elements of indigenous cultures. According to Haverfield this eventually led to the widespread presence of ' $[\mathrm{t}] \mathrm{he}$ definite and coherent culture of Rome' in the Empire's western provinces. ${ }^{44}$

Since the descriptions in Hawkins' and Franks' guidebooks are very brief, it is almost impossible to reconstruct the way in which the Roman antiquities were displayed in the nineteenth-century British and Mediaeval Room. What little can be said is that the objects were arranged by type, which was very common throughout the nineteenth and early twentieth century. The 1859 guidebook, for instance, mentions that cases 52 and 53 contained examples of locally produced Roman pottery which were 'found on the site of the kilns in which they were manufactured', while cases 58 and 59 held imported red-gloss Roman pottery 'called Samian' ${ }^{45}$ In 1859, the British and Mediaeval Room numbered a grand total of 97 cases, 33 of which housed Romano-British antiquities, and four table cases, one with objects from Roach Smith's collection. ${ }^{46}$ In 1877, the British and Mediaeval Room housed 96 cases in total, 33 of which still held Roman material, ten table cases and at least two upright cases. Two of the ten table cases contained Roman material and one of those still held objects from Roach Smith's

40 Wilson 2002, 101. Naturally, assessments of inflation over such a long period of time have to be taken with a pinch of salt. This estimation of the present-day value of money in 1859 is based on the 2003 index (amended in 2014) agreed between the Office of National Statistics, the Bank of England, and the House of Commons Library. For more information see Allen 2014.

41 Hawkins 1859, 99-100.

42 Franks 1869, 123-4; 1871, 126-7; 1877, 133-4.

43 Hawkins 1859, 99; Franks 1869, 123; 1871, 126; 1877, 133-4.

44 Haverfield 1915, 11-14. Haverfield did, however, observe that (particularly with regard to religion) Roman and native customs and traditions sometimes existed alongside each other and often mingled to form what we would now call new 'hybrid' cultures, see Haverfield 1915, 20-2.

45 Hawkins 1859, 100.

46 Hawkins 1859, 100. 
collection. ${ }^{47}$ A photograph of the British and Mediaeval Room from 1875 shows that the table cases occupied a central position in the room (FIG. 1). The importance of Roach Smith's collection to the collections of Romano-British antiquities was thus emphasised through its prominent position.

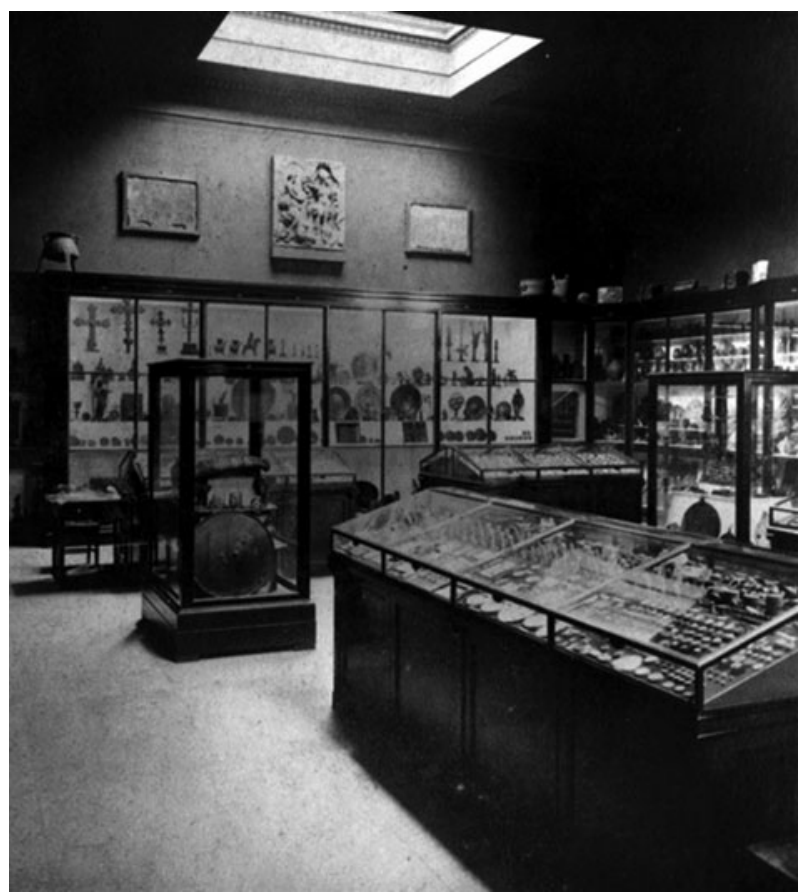

FIG. 1. The British and Mediaeval Room c. 1875. (The British Museum Central Archive, York Album 119; (C) The Trustees of the British Museum)

\section{THE ORIGINS OF THE ROMANO-BRITISH COLLECTIONS OF THE MUSEUM OF LONDON}

The present-day Museum of London is the result of an amalgamation of two earlier museums: the Guildhall Museum and the London Museum. The former was created as something of an afterthought to the Guildhall Library, founded in 1824. The library was the brainchild of Richard Jones (1783-1863), who was a representative on the Common Council (the City of London Corporation's principal assembly) from 1819 until his retirement in 1852. By the time the library opened in 1828 , the Guildhall Museum had also taken shape, reflecting an intention to create a collection of antiquities which had been expressed by the Common Council in 1826 . In 1829, librarian William Herbert (1771-1851) reported that the foundation for such a collection had been laid, adding that it was, at present, too small to generate much interest. Nevertheless, this modest collection formed the nucleus around which the collection of antiquities found in the City of London would continue to grow. ${ }^{48}$

\section{Franks 1877, 131-7.}

48 Sheppard 1991, 7-8. 
The museum was rarely a priority for the City Corporation, the Library Committee or the Librarian. Notwithstanding, its collections steadily grew due to the discoveries made during construction work in the City of London. Some of the objects uncovered during building works were bought by the museum, but the vast majority were donated. Ironically, one of the more generous benefactors, whose donations would help to expand the museum's collections, was Roach Smith. This was ironic because Roach Smith was one of the most vocal critics of the City Corporation during the 1840 s when he regularly condemned the City Corporation for not doing enough to protect the material remains of Roman London from the destruction caused by construction works. He tried to save at least some of this material by buying objects directly from the labourers who had uncovered them. Despite his criticism and the mutual animosity between him and members of the City Corporation, Roach Smith regularly offered items from his own collection of antiquities to the Guildhall Museum. In spite of Roach Smith's frequent donations, the Library Committee failed to make a decision with regard to the purchase of his valuable collection of antiquities when he offered it up for sale to both the British Museum and the Guildhall Museum in 1855. Consequently, the Trustees of the British Museum, who had initially refused to provide the necessary funds, were able to procure the collection when a second opportunity presented itself in 1856. The Guildhall Museum would never again be presented with the opportunity to acquire a collection of London antiquities which was as large and as valuable as Roach Smith's. ${ }^{49}$

The appointment of William Overall (1829-88) to the position of librarian in 1865 had a positive impact on the museum, for he was not just interested in the library, but also in the museum. In 1866, he persuaded the City Corporation to finance the construction of a much needed new building for both the library and the museum. The library, which was located on the ground floor of the new building, opened in 1872, while the museum, which was located in the poorly illuminated and stuffy basement, opened two years later in 1874 . The reason for this delay was because the Library Committee had doubts about the museum's collections of antiquities, which were supposedly too small to be turned into an adequate display. ${ }^{50}$ Considering that nearly all the museum's antiquities came from within the boundaries of the City of London, a somewhat illogical solution presented itself when two large sculptured slabs from Nineveh were donated to the museum. This lack of focus would persist for years; in 1884, for example, the museum accepted a donation of two Assyrian sculptures, while refusing to accept the offer of an 'ancient stone coffin' found in the City of London. The illogical presence of the Assyrian material ended in 1903, when it was transferred to the British Museum. ${ }^{51}$

Encouraged by learned societies such as the London and Middlesex Archaeological Society (founded in 1855), the City Corporation slowly began to take a more active interest in the archaeology of the City during the 1870s. Thus, when the opportunity presented itself to purchase the late John Walker Baily's (1809-73) collection of antiquities in 1881, the Corporation quickly agreed to buy it for its asking price. Although far from as large as Roach Smith's collection, Baily — who had headed a firm of iron merchants - had put together a sizeable collection of mainly Roman antiquities found in the City during the last decade of his life. This and similar, though smaller, acquisitions made sure that the museum's collection of Romano-British antiquities grew steadily. In 1888, the Library Committee considered the collection of Roman and other antiquities in the museum large enough to justify the creation of

49 Sheppard 1991, 8-16, 18-20.

50 As is mentioned in Section 1 of this paper, Edward Hawkins had voiced a similar opinion some twenty years earlier (in 1851) with regard to the collection of British antiquities in the British Museum — a defect which was remedied by the acquisition of the Roach Smith collection.

51 Sheppard 1991, 21-5, 30 . 
a catalogue. This also entailed labelling the objects displayed in the museum, which, hitherto, had not been accompanied by descriptive labels. ${ }^{52}$

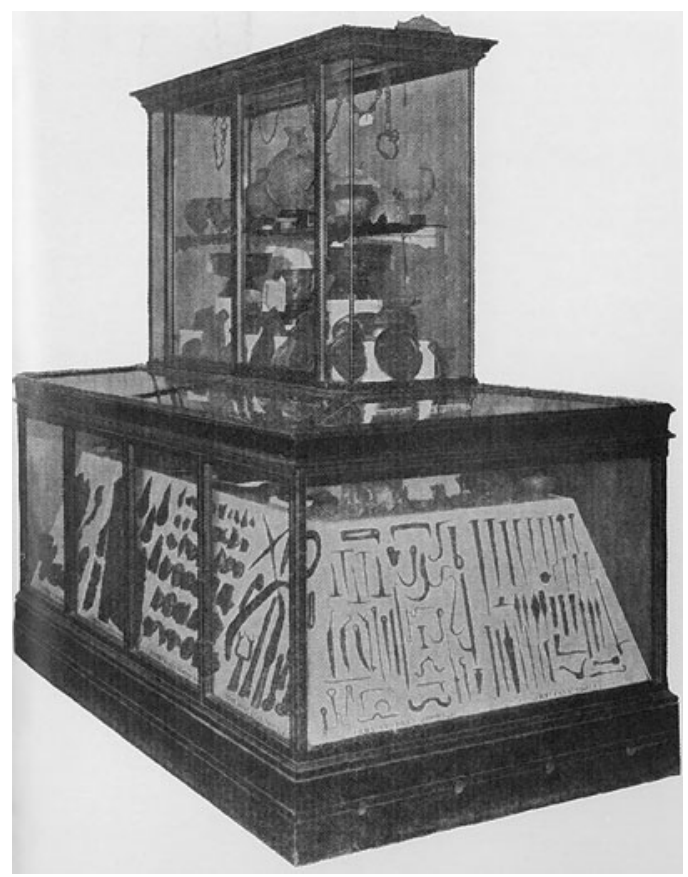

FIG. 2. Case with antiquities in the Guildhall Museum, photograph taken c. 1875. (Sheppard 1991, 27; (C) Museum of London)

A photograph of a case of antiquities taken around 1875 (FIG. 2) shows that the antiquities were arranged by type - with, for instance, pottery and pottery fragments in the upper part of the case and 'artisans' tools' below on the right - as was also the case in the British Museum and most other museums at this time. Unfortunately, it is impossible to reconstruct the way in which the collection of Romano-British antiquities was displayed during this period - let alone try to find out how the objects were interpreted - due to the absence of guidebooks for this, or any other part, of the museum's collections during the nineteenth century. Even the catalogue which was not completed until 1903 with an updated reprint in 1908 - offers few clues, since it does little more than provide a general overview of the objects which were owned by the museum (without, for example, making clear which objects were displayed in the museum at that time). Almost a quarter of the catalogue - 95 out of a total of 411 pages - is devoted to the museum's Roman antiquities. ${ }^{53}$

Sheppard 1991, 25-9.

Guildhall Museum 1908, 23-118. 


\section{THE ROMANO-BRITISH COLLECTIONS OF THE BRITISH MUSEUM IN THE TWENTIETH CENTURY}

On Boxing Day 1918, a new Room of Roman Britain was opened in a room near the top of the main staircase. ${ }^{54}$ It is currently used for a display of objects from medieval Europe between 1050 and 1500 (Room 40). A new guidebook to its contents was published by the museum in 1922 . It was written by Reginald Smith (1873-1940), an archaeologist who had joined the Department of British and Mediaeval Antiquities and Ethnography as an assistant in 1898. Smith had become Deputy Keeper in 1921 and was responsible for the archaeological material in the Department of British and Mediaeval Antiquities (the ethnographical collections had been ceded from the department). ${ }^{55}$ Smith's archaeological background is evident in the pages of his guidebook, which numbered no fewer than 136 pages - quite a difference compared to the meagre total of two pages which were devoted to the Romano-British collections in each of the four guidebooks published in the previous century. Smith's guidebook offers a wealth of information about the objects displayed in the Room of Roman Britain and provides some much needed context. From the table of contents we learn that the objects were still arranged in the traditional manner, grouped together by type. Table case D, for example, held, among other things, an impressive collection of spoons, plate and jewellery, while table cases 10 to 16 contained Samian ware. There were a few exceptions to this general rule, the common denominator of the objects displayed in table case A, for instance, was that they were all found in caves. ${ }^{56}$ In addition to containing much more informative descriptions of the objects, the 1922 guidebook also differs from earlier versions in the large number of illustrations which enliven the volume and enhance the descriptions of some of the objects.

By the end of the nineteenth century, much had been done to transform British archaeology into a rigorous academic discipline by, among others, Augustus Pitt-Rivers (1827-1900), who had put great effort into improving the standards of excavation and recording. ${ }^{57}$ With regard to Romano-British archaeology in particular, Haverfield had done much to professionalise the discipline, recognising the potential of Romano-British archaeology to shed some light on life in a province which is poorly documented in ancient texts. ${ }^{58}$ Despite this, and in spite of his own background in archaeology and the archaeological nature of the collection he curated, Smith frequently relied on the authority of Tacitus' Agricola when describing Roman Britain in the first century A.D. in his introduction to the 1922 guidebook. This should not surprise us, since the corpus of classical texts, until quite recently, occupied a position of nearly unchallengeable authority because they were perceived as the great repository of Western civilisation. ${ }^{59}$ As a consequence, the introduction provides an account of the Romans in Britain instead of an account of Roman Britain. It is possible that this was partly due to a realisation that the museum's collections of antiquities were, although extensive, far from complete. Awareness of this fact would slow down the production of guidebooks in the other antiquities departments in the 1930s and during the 1940s none at all were produced. ${ }^{60}$ The first guidebook to be published about the Romano-British collections after that of 1922, for instance, would be that of $1951 .{ }^{61}$ Therefore, Smith may have been reluctant to provide an overview of the history of Roman Britain based mainly on the archaeological material.

54 Smith 1922, v.

55 Wilson 2002, 199-200, 224, 235.

56 Smith 1922, vii, 49.

57 Bowden 1991, 154-67.

58 Freeman 1996, 19; Hingley 2000, 12-14.

59 Grew 2001, 18.

60 Wilson 2002, 245.

61 Brailsford 1951. 


\section{The representation of the material culture of Roman Britain}

In a recent paper about the history of the Romano-British collections displayed in the British Museum, American art historian Nancy Netzer suggested another reason for Smith's reluctance to produce a mainly archaeological account — an inferiority complex when it came to his estimation of the quality of archaeological finds from Roman Britain compared with those found on the Continent. ${ }^{62}$ This becomes evident in the following passage from Smith's introduction to the 1922 guidebook:

The Romans left little of permanent value behind them in this country. (...) Compared with the Continent, the material relics of their occupation in Britain are meagre and unattractive. No triumphal arches, no temples, aqueducts, or amphitheatres of stone remain with us to testify the splendour of Rome: only the wreck of Hadrian's Wall, and here and there remains of town walls or country-houses. (...) [B]oth in quantity and quality Roman antiquities abroad, whether in the field or in museums, dwarf into insignificance most of the achievements of four centuries in Britain. ${ }^{63}$

After reading this, it is hard to imagine why people even bothered to visit the Room of Roman Britain, especially since the disparaging tone resurfaces more than once in the remainder of Smith's guidebook. This mainly occurs when he evaluates the quality of works of art, which are frequently dismissed as 'provincial' and inferior to classical examples. ${ }^{64}$ This probably led Smith to describe a bronze statuette of Mars he obviously admired as 'of unusual quality for Britain'. ${ }^{65} \mathrm{He}$ did not, however, suggest that it was imported from the Continent, something which the classical archaeologist and art historian Jocelyn Toynbee (1897-1985) would do 40 years later. She attributed objects which, in her opinion, were of the finest quality to craftsmen from the Mediterranean Basin and objects of lesser, but still high, quality to craftsmen from Gaul. ${ }^{66}$ In many ways this was a step back from the view which Hawkins and Franks had expressed in their guides to the Romano-British antiquities — that the overall majority of Roman antiquities found in Britain was also produced there. As mentioned above, it is even possible that Franks explicitly criticised the view that material culture from Roman Britain was inferior to that of regions nearer to Rome. Smith's and Toynbee's views show that this preconceived bias was as prevalent in the first half of the twentieth century as it had been in 1850 .

\section{The representation of the Roman military and the spread of 'civilisation'}

Returning to Smith's 1922 guidebook, it is worthwhile drawing attention to another passage from the introduction. After briefly describing the various military campaigns by Roman generals and rebellions by local tribes, Smith concludes that ' $[t]$ he Roman history of Britain is mainly military and the occupation was of the same character'. ${ }^{67}$ This view had become outdated by this time, largely due to the efforts of Haverfield. In successive editions of his highly influential monograph The Romanization of Roman Britain, Haverfield emphasised that the culture of Roman Britain was largely similar to that of the continental Roman provinces. Dividing Roman Britain into a 'civil' and 'military' district, he argued that only the north and west of the province should be seen as highly militarised. Haverfield suggested that a one-sided reliance on

\footnotetext{
Netzer 2014, 201-2.

Smith 1922, 10.

Netzer 2014, 201, with references.

Smith 1922, 89.

Netzer 2014, 202, with references.

Smith 1922, 6.
} 
the writings of Caesar and Tacitus had caused previous generations of scholars to believe that the history of Roman Britain was primarily shaped by the Roman military. ${ }^{68}$ This seems to be an accurate assessment, for Smith's heavy reliance on the Agricola appears to have been one of the factors which inspired his image of Roman Britain as a militarised province. Tacitus' Agricola includes its fair share of military action and the museum's Romano-British collections contain a large collection of Roman militaria. In addition, most of the epigraphic material (stone inscriptions) originates from soldiers who served in the Roman army. ${ }^{69}$ It is likely that all of these factors in combination led Smith to assume that Britain was a militarised province. Smith's account of the end of Roman rule in Britain suggests a direct link between the definite removal of a Roman military presence and the disappearance of what, taken together, might be called 'civilisation':

In 410 they received a message from the Emperor Honorius that henceforth they could count on no one but themselves. Britain was no longer a province of the Empire. The Romans left little of permanent value behind them in this country. Their system of government, their laws and institutions, religion, language and writing, science and learning were all but ruined in the next two centuries, and had to be slowly and painfully re-introduced for the benefit of our Anglo-Saxon forefathers. ${ }^{70}$

The end of Roman rule is clearly represented as a bad thing, but the words 'left little (...) behind' are particularly interesting. They seem to refer to the final departure of Roman troops from Britain, who took with them what Smith presumably believed to be theirs: an organised government, the rule of law, literacy, in short, all the supposed benefits of civilisation and empire. In a similar vein, Haverfield had also associated the presence of the Roman military with the presence of civilisation:

The lands which the legions sheltered were not merely blessed with quiet. They were also given a civilization, and that civilization had time to take strong root. Roman speech and manners were diffused; the political franchise was extended; city life was established; the provincial populations were assimilated in an orderly and coherent culture. A large part of the world became Romanized. ${ }^{71}$

Whereas people living in the Roman provinces like Britain were 'given' civilisation in Haverfield's narrative, they were deprived of it when the Romans left again and 'left little behind' in Smith's account. Although Smith did not use the term 'Romanisation' in his 1922 guidebook, a similar one-sided view of interaction between an imperial power and its provincial subjects is present in its contents. Views like these were no doubt inspired by the contemporary impact of British imperialism.

In the second half of the twentieth century, the collection of Roman militaria had literally been given an exalted position in a refurbished Roman Room. According to a very brief description of the room in 1986 (no guidebooks with more detailed descriptions are available for this period) 'objects mainly relating to the army in Roman Britain' were located on a mezzanine which had been created in the Room of Roman Britain. ${ }^{72}$ A photograph taken during the 1980s clearly shows this intermediate floor, complete with a balustrade which, considering the Roman militaria displayed on the mezzanine, aptly invokes the battlements of a Roman fort (FIG. 3).

68

69

70

71

72

Hingley 2008, 313-15, 319.

Mattingly 2007, 202.

Smith 1922, 10.

Haverfield 1915, 11.

Rogers 1986, 35. 


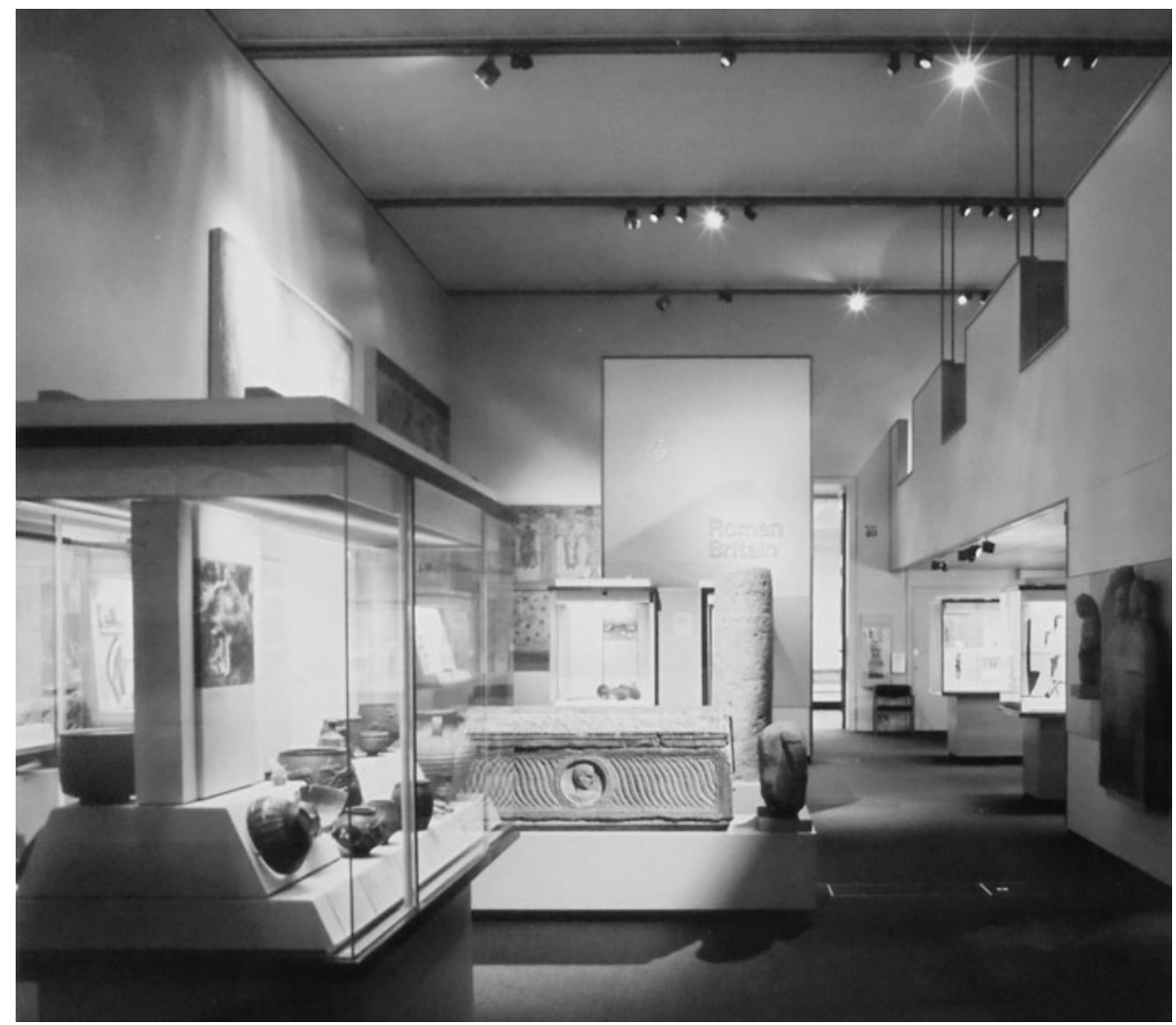

FIG. 3. The Room of Roman Britain, photograph taken during the 1980s. (The British Museum Central Archive; (C) The Trustees of the British Museum)

\section{THE ROMANO-BRITISH COLLECTIONS OF THE GUILDHALL MUSEUM AND THE LONDON MUSEUM IN} THE TWENTIETH CENTURY

For reasons of clarity and coherence this section is divided into three parts: the first will deal with the twentieth-century history of the Romano-British collection of the Guildhall Museum, the second part with that of the London Museum, while the third and final part will focus on the amalgamated collection in the newly created Museum of London, which opened in 1976.

\section{The Guildhall Museum}

During the first decade of the twentieth century, the Guildhall Museum gained some independence from the Guildhall Library and was given a more professional basis. In 1907 the Cambridgeeducated archaeologist Frank Lambert (1884-1973) became the museum's first keeper (or 'clerk', since this was the somewhat pejorative term used by the City Corporation). Apart from his museum duties, Lambert's remit also included monitoring all construction sites in the City of London to ensure that antiquities there were recorded and, in some cases, preserved in the museum. Although it was an impossible job for any one person to keep an eye on all building sites, the City Corporation had finally acknowledged its responsibility to preserve the buried remains of London's past for future generations by including this in Lambert's brief. Lambert 
made the museum's collections more accessible to the public by adding large general labels to the displays which can be compared with information panels in modern museums. In addition, he encouraged local schools to visit the museum. ${ }^{73}$ Based on a photograph of the museum in 1927 (FIG. 4), he does not seem to have made significant changes to the typological arrangement of the objects. The museum's impressive collection of spoons (the 1908 catalogue lists 35, mostly bronze, spoons for the Roman period alone $)^{74}$ is clearly visible in this photograph.

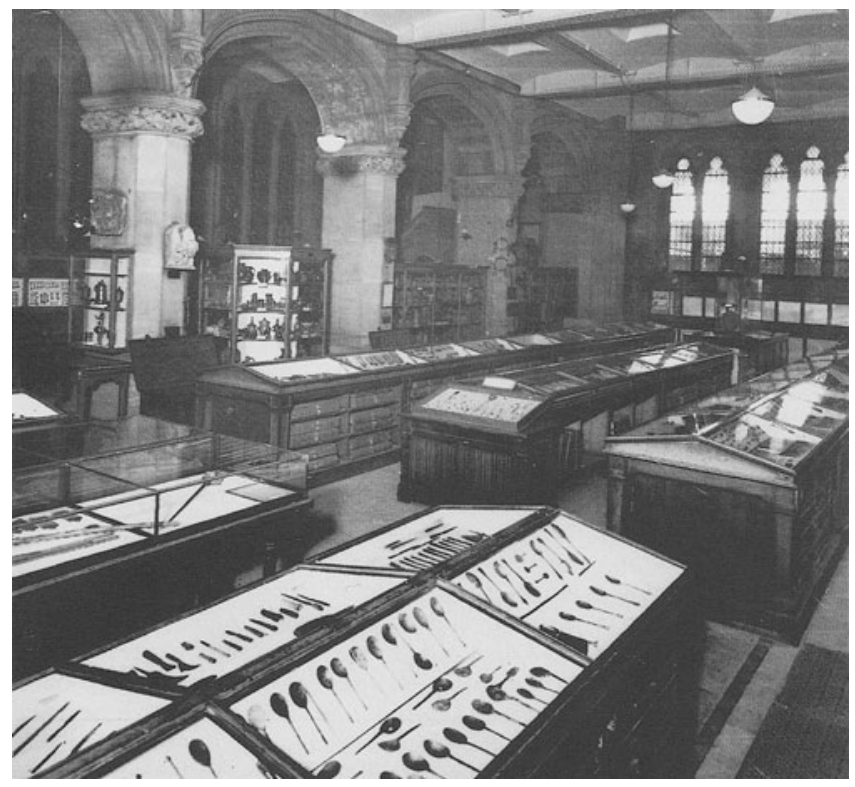

FIG. 4. The Guildhall Museum in 1927. (Sheppard 1991, 135; C Corporation of London: London Metropolitan Archives)

The Guildhall Museum emerged relatively unscathed from the Second World War. Unfortunately, the same could not be said for large parts of London. The rebuilding which would take place on the bombed sites in the decades to come presented fresh challenges to the staff of the Guildhall Museum, the unprecedented number of construction sites representing a unique opportunity for archaeological investigation of London's past. Regrettably, the archaeological staff of the Guildhall Museum was too small and often lacked the funds to effectively make use of this opportunity. Although the museum remained active in recording the objects found at various building sites throughout the City, much of the new material which entered its collections came not from sites excavated by museum staff, but from more than 50 scientific excavations made by William Grimes (1905-88), the director of the London Museum. One of the best known was that of the Mithraeum at a building site at Walbrook between 1950 and 1951, a dig which was later resumed between 1954 and 1955. High-profile finds - like the head of Mithras, which was uncovered by Grimes' team in 1954 - gave the Guildhall Museum some much-needed publicity. ${ }^{75}$

73 Sheppard 1991, 30, 133-4.

74 Guildhall Museum 1908, 39-40.

75 Sheppard 1991, 142-3, 145-9. 
The museum itself went through a difficult period in the post-War years, moving from one location to another. In 1966, the Guildhall Museum was finally separated from the Guildhall Library and nine years later, in 1975, the museum merged with the London Museum, thereby ending its 149 -year history. ${ }^{76}$ Since 1908 , no catalogues or guidebooks had been published by the Guildhall Museum. Given this lack of information, it is impossible even to attempt to reconstruct the way in which antiquities found in the City of London were displayed in the museum during the post-Second World War period.

\section{The London Museum}

The creation of the London Museum was officially announced in The Times on 25 March 1911. The museum was the brainchild of Lewis Harcourt, first Viscount Harcourt (1863-1922), a member of an ancient aristocratic family, and his close friend Reginald Brett, second Viscount Esher (1852-1930), who was also a member of an ancient, although less prominent, aristocratic family. Ever since they had visited the Musée Carnavalet in Paris in 1890, quite possibly together, Harcourt in particular had wanted to create a similar museum in London. The Carnavalet Museum first opened in 1881 and its collections displayed (and continue to do so today) the history of Paris. Since London lacked a comparable museum — the Guildhall Museum concerned itself with the early history of the City of London, ignoring the history of nine-tenths of the capital and its more recent history - Harcourt, supported by Esher, wanted to create a 'London Carnavalet'. Using their extensive social and political connections, they managed to do so in 1911. The London Museum was founded without any involvement of the City Corporation and without financial support from the London County Council, the necessary funds being provided by a private benefactor. It proved difficult to find a suitable home for the museum, but, with the help of Esher's close ties to the royal family, it eventually found a temporary one in Kensington Palace and opened its doors to the public on 8 April 1912. ${ }^{77}$

Sir Guy Laking (1875-1919) was the first keeper of the London Museum, having previously been keeper of the King's Armoury at Windsor. The nucleus of the museum's collection of Romano-British material was formed by the Roman antiquities in the Hilton Price collection of London antiquities, which were bought for the museum by Harcourt in 1910. This collection was augmented by donations and by the regular purchase of newly discovered archaeological material uncovered during construction work in London. In addition, Harcourt was able to persuade the London County Council to surrender its collection of antiquities to the museum. The museum's collections were arranged by type, which can be inferred from a floor plan of the museum. ${ }^{78}$ According to a guidebook published by the museum in 1912, most of the Romano-British material was displayed in Queen Mary's Gallery. The guidebook hints at a connection between the presence of civilisation and the presence of the Roman army and other Roman state officials, for whereas the contents of case 2 in Queen Mary's Gallery are described as objects which represent 'the high state of civilisation and luxury of domestic life in Roman London', the contents of case 3 are described as objects which represent the period after the Romans left London, leading to a 'relapse to barbarism'. ${ }^{79}$ As noted above, the contemporary experience of the British Empire would also cause others to associate the presence of the Roman military and other state officials with the presence of civilisation.

In April 1913, the London Museum was presented with a more permanent home in the form of Stafford House (renamed Lancaster House in 1914), which had been bought by Sir William Lever

Sheppard 1991, 142, 149-58.

Sheppard 1991, 33-45, 60-1.

Sheppard 1991, 37, 40, 44-51, 62.

Law 1912, 81 . 
(1851-1925), a wealthy soap manufacturer, the year before. In the autumn of 1913, all the museum's collections moved to their new home, which opened its doors to the public in 1914. ${ }^{80}$ A guidebook, published as part of the Treasure-House Series in that year, shows that the museum was now arranged chronologically, in contrast with the way in which the collections had been exhibited at Kensington Palace, although the objects themselves were still grouped together by type in each gallery. In the section which deals with the objects in the Roman Room, for instance, mention is made of a case containing pottery of various types, while another, smaller case is said to have contained coins. ${ }^{81}$ Unfortunately, the guide does not provide a detailed description of all the cases in the Roman Room. Neither does it offer the reader an insight into how Roman London was represented in this room by drawing attention to the information on the labels which accompanied the displayed objects. Instead, the writer provides his readers with his own description of the history of Roman London. ${ }^{82}$

It was not until after the appointment of Sir Mortimer Wheeler (1890-1976) to the position of keeper in 1926 that the museum would again publish its own guidebooks. Wheeler - who had just given up his position as director of the National Museum of Wales - did not think much of the museum when he arrived, describing it as 'derelict' and as a 'junk shop' in his autobiography. He described the task which faced him (undoubtedly not without a little self-promotion) as follows: 'The London Museum had to be cleaned, expurgated and catalogued; in general, turned from a junkshop into a tolerably rational institution. ${ }^{83}$ Wheeler did not waste time and started to rearrange the museum's displays shortly after his arrival in July 1926. He also energetically started work on a concise general guide to the museum's collections, which was finished and published before the year was out. From 1927 onward, Wheeler would work on several more detailed guidebooks on specific parts of the collections. ${ }^{84}$

\section{The representation of Roman imperialism and the Roman military}

That Wheeler, like so many of his colleagues at that time, identified the workings of Roman imperialism with that of the British Empire becomes clear in the following passage from his 1930 catalogue of Romano-British objects in the London Museum: ${ }^{85}$

Latin writers tell us how, in Austria, Gaul and elsewhere, Roman traders preceded the 'flag' and, often at the peril of their lives, opened up commercial relations with the peoples beyond the Roman frontiers. ${ }^{86}$

The concept of 'trade before the flag' was a modern one, which was sometimes used to describe contemporary British imperial policy. It should be noted, however, that Wheeler's use of inverted commas around the word 'flag' indicates that Wheeler may very well have considered his comparison of Roman imperialism with British imperial policy rather strained. Nevertheless, Wheeler's choice of words does suggest a sympathetic identification particularly with the Roman military, reinforced perhaps by his own career in military service. Writing about the invading Roman army, for instance, he contended: 'With unerring judgement, these pioneers of imperial civilization were already concentrating upon the river-crossing at London. ${ }^{\text {} 87}$ The Roman soldiers are tellingly described as 'pioneers of imperial civilization'. As

80 Sheppard 1991, 73, 76-7, 79-80.

81 Darton 1914, ix, 17, 19.

82 Darton 1914, 16-31.

83 Wheeler $1955,83-4$.

84 Sheppard 1991, 103.

85 Grew 2001, 16.

86 Wheeler $1930,17$.

87 Wheeler 1930, 12. 
noted above, a similar close association between the presence of civilisation and the Roman military was present in Smith's 1922 guidebook to the Romano-British antiquities in the British Museum and in Haverfield's The Romanization of Roman Britain, while it is also implied by the author of the 1912 guidebook of the London Museum. Whereas Wheeler endows the Roman conquerors with 'unerring judgement', he describes the native population of northern Wales as 'obstinate' because they offered armed resistance. ${ }^{88}$

Whether Wheeler's identification with the Roman military and his belief in the benign nature of Roman imperialism were evident in the Roman Room of the London Museum is difficult to say. His 1926 Guide to the Roman Room certainly does, again, make clear that he linked the presence of civilisation in London and its surroundings with the Roman conquest. With regards to material culture of a pre-Roman date from London, he remarks that 'these mark the existence of a semi-civilized people', 89 while he describes the advent of Rome as follows: "With the consolidation of this district by a civilized power would come improved trade, imports from Italy and other countries would "follow the Eagles". 90 Based on the contents of Wheeler's guidebook, the Roman Room seems to have accommodated eight cases. Unfortunately, it remains unclear how these were arranged in the absence of a floorplan of this room. What can be said with certainty, however, is that the objects within these cases were grouped together by type. In August 1939, the outbreak of war being almost certain, the museum was closed and the collections moved to safer places. This effectively marked the end of Wheeler's keepership (he resigned in February 1944 after he had accepted the post of Director of Archaeology in India). ${ }^{91}$

During the War, the Foreign Office took possession of Lancaster House and - despite attempts to regain it for the London Museum after the War - remains its owner to this day. In November 1945, Grimes became the new keeper (later director from 1947) of a museum without a home. This situation ended in 1948, when, with the help of George VI, the London Museum returned to Kensington Palace. Grimes reorganised the museum's internal structure, creating four departments: Prehistoric, Roman and Dark Age (headed by Grimes himself); Medieval; Tudor and Stewart; and the rather uninspiringly named 'Modern Department'. In addition to his work inside the museum, Grimes remained an active archaeologist, having initiated and overseen over 50 excavations in the City. The objects unearthed during these investigations were given to the Guildhall Museum (they were found in its territory after all), which greatly helped to improve the relations between the two museums, making the idea of amalgamation more appealing than it had been before. ${ }^{92}$ A guidebook written in 1960 by Donald Harden (190194), the London Museum's last director, provides a brief description of the history of Roman London, but offers very little information about the Roman gallery's contents or the way in which Roman London was represented. It does, however, mention that smaller objects from Roman London were arranged both thematically and by type in cases dealing with 'religion and art, burial customs, household and industrial equipment, personal adornment and metal work, glass and pottery'. ${ }^{93}$ This indicates that the transition from displays in which the objects were arranged by type (as had been the case throughout much of the history of the London Museum) to displays in which the objects were arranged thematically (as would be the case in the Museum of London) had already begun during the London Museum's later years.

Wheeler 1930, 21.

Wheeler 1926, 5.

Wheeler 1926, 3.

Sheppard 1991, 113-14.

Sheppard 1991, 114-15, 118, 121, 162.

Harden 1960, 11. 


\section{The Museum of London}

The Guildhall Museum and the London Museum were officially merged to form the Museum of London on 1 June 1975. Thomas Hume (1917-92) became the Museum of London's first director in the summer of 1972 until his retirement in 1977. In this time, he successfully merged the staff and the collections of the new museum's predecessors into a coherent new entity. Hume had extensive museum experience, which made him the ideal candidate for organising the new museum. He made sure that the galleries in the museum all conformed to a general layout, for example with respect to the texts on labels and information panels. A three-tier system was developed throughout the museum with panels providing general background information on a particular period, panels with information on a particular subject within those periods and, of course, the labels which accompanied each individual object in the displays. This system strengthened the coherence between the galleries, each representing an individual historical period, in line with the museum's intent to present the biography of London. The initial allocation of floor space was somewhat unbalanced, for the galleries of the Roman and Medieval periods were allotted more space than was assigned to the whole period from 1700 onward. This defect was, however, quickly corrected. ${ }^{94}$ Doubtless, the initial imbalance was due to the large amount of Roman (and Medieval) antiquities and comparatively small amount of later material in what came from the collections of the Guildhall Museum. ${ }^{95}$ Work on the exhibition galleries began during the early months of 1975 and on 3 December 1976, 17 years after amalgamation had first been seriously discussed, the Museum of London finally opened its doors to the public. ${ }^{96}$

The museum's ambition to present the biography of London translated into a sequence of galleries whose contents provide visitors with a continuous narrative of London's history. The gallery of Roman London is naturally located near the beginning of that sequence after the prehistoric gallery. As Francis Grew - senior curator of archaeology at the Museum of London - has pointed out, this ambition would, unintentionally, also have a negative side effect, for the impression was created 'that modern, successful London follows in a direct line from ancient, successful, Roman London'. ${ }^{97}$ In the 1976 museum guidebook, for example, it is stated that 'London began in A.D. 43 when the Roman invaders built a bridge just above the tidal limit of the Thames'. ${ }^{98}$ The 1995 guidebook, published one year before a refurbished Roman London gallery re-opened in 1996, contains a similar statement: 'The Romans created the settlement of Londinium, thus founding what was to become the modern City of London, lying at the centre of the metropolis.' 99 Consequently, while the origins of modern London lie in the medieval city which was founded to the west of the remains of the Roman city, visitors may have been led to believe that London was continuously inhabited from the Roman period until the present. This was largely due to the museum's ambition to present a biography of London, since the concept of a biography naturally implies continuous existence without interruptions.

\section{The representation of the Roman military}

In his 2001 paper, Grew also questioned the conventional view that London's garrison had an exclusively administrative and ceremonial function, suggesting that this idea may,

94 Sheppard 1991, 171-3.

95 Museum of London 1988, 13.

96 Sheppard 1991, 173-4.

97 Grew 2001, 12.

98 Museum of London 1976, section titled 'Roman London'.

99 Museum of London 1995, 12-13. 
subconsciously, draw on 'perceptions of the present-day role of the armed services in London pageantry'. ${ }^{100}$ A striking example of such a view can be found in Merrifield's A Handbook to Roman London, published in 1978 by the Museum of London (of which he was Senior Keeper and Deputy Director from 1975 and 1977 respectively, fulfilling both functions until his retirement in 1978). With regard to the Cripplegate fort, Merrifield asserts that:

Its purpose was probably not so much to defend London from attack, as to provide a suitable barracks for the troops who were necessarily stationed in the capital city - soldiers for guard duties, escorts and ceremonial, like those in London to-day. ${ }^{101}$

This is an excellent example of how the contemporary experience of, in this case, the role of soldiers in (Western) society is uncritically projected back onto the past to give meaning to its material remains. While no serious scholar would, today, deny that at least some of the people living near Roman Britain's northern frontier would have experienced the presence and activities of Roman soldiers as a source of repression, Grew went further by asking the question whether Roman soldiers stationed in civilian areas such as London might - contrary to the conventional view - not also have acted, or been experienced, as a repressive force. ${ }^{102}$ This question definitely deserves to be asked, particularly with regard to the current representation of the Roman military in the Roman London gallery of the Museum of London.

\section{THE ROMANO-BRITISH COLLECTIONS OF THE BRITISH MUSEUM TODAY AND THE IMPACT OF POST-COLONIAL CRITICISM}

The Weston Gallery (Room 49) is the room which currently houses the display on Roman Britain. The gallery was opened in 1997 and re-opened on 16 June 2007 after some essential refurbishment. ${ }^{103}$ Compared with its rather cramped quarters in the British and Mediaeval Room (Room 69) between 1851 and 1899 and in the Room of Roman Britain (Room 40), where the collection was on display from 1918 onward, the Weston Gallery provides spacious accommodation for the Romano-British antiquities. Even so, the room still lacks the space necessary to exhibit some of the larger objects such as the complete mosaic floor from the villa of Hinton St Mary (only a small part of which is currently on display). It is estimated that, in order to be able to display the entire collection, a gallery three times as large as Room 49 would be necessary. ${ }^{104}$ The room is located on the upper floor on the east side of the building; the room of the same size located opposite to Room 49 on the west side of the building is the Wolfson Gallery (Room 70) which houses antiquities from all over the Roman Empire. This is probably a coincidence, but could be seen as a symbolic indication that the material remains from Roman Britain are no longer perceived as inferior to, but rather seen as on par with those from the Continent. ${ }^{105}$

\footnotetext{
100 Grew 2001, 20-1.

101 Merrifield 1978, 17.

102 Grew 2001, 21.

103 Jackson $2007,8$.

104 Johns 1997/2000, 4.

105 In contrast, Netzer has argued that the physical distance between the rooms which house the museum's Greek and Roman antiquities and the room which houses the Romano-British antiquities still reflects the outdated notion that the latter are in some way inferior to the former, see Netzer 2014, 203.
} 


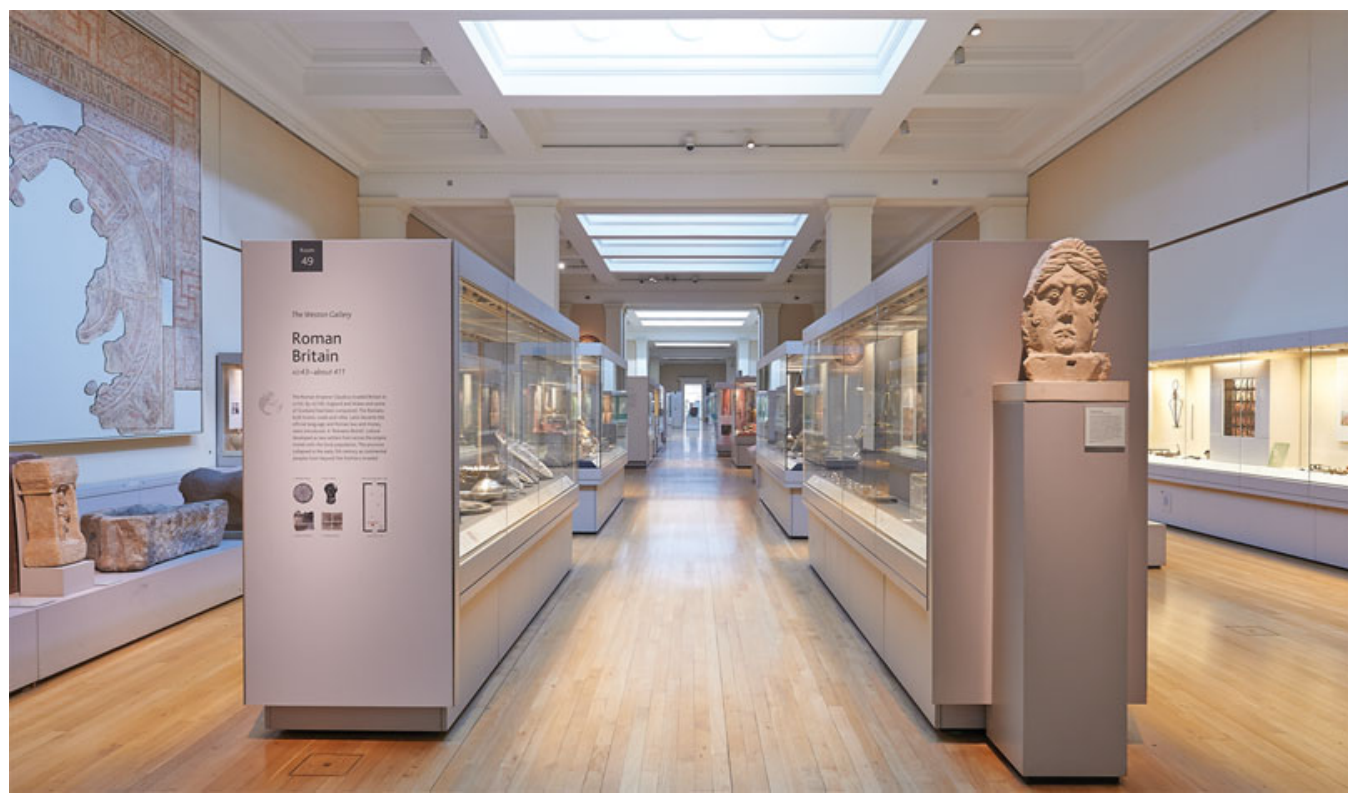

FIG. 5. The Weston Gallery of Roman Britain in 2015, photographed from its southern entrance. (British Museum Images; (C) The Trustees of the British Museum)

The objects in the Roman Britain gallery are, to some degree, arranged chronologically, as most objects in the northern half of the gallery (bordering on Room 50) date back to the first or second century, while most objects in its southern half (bordering on Room 41) are from the third or fourth century. Visitors are thus given the opportunity to make a journey in time, either by moving forward in time when they enter the gallery from Room 50 (with a display on 'Britain and Europe, 800 B.C.-A.D. 43'), or by travelling back in time when they enter the gallery from Room 41 (with a display on 'Sutton Hoo and Europe, A.D. 300-1100'). There is a central walkway in the middle of the room, flanked by upright and table cases; the walls are partly lined by wall cases, which on occasion make room for mosaics mounted on the walls; finally, large stone monuments - predominantly tombstones and altar stones - are placed on low plinths throughout the gallery or mounted on its walls (FIG. 5). Panels provide background information on a wide variety of themes, such as 'language and literacy', 'hygiene and health', 'the role of the army in Britain', 'coinage in Roman Britain' and 'eating and drinking'. More detailed information on individual objects is provided by accompanying labels, complete with registration numbers which are especially useful for researchers.

\section{The representation of processes of cultural change}

Information panels attached to the side of two upright cases flanking the central walkway and near the entrances provide an introductory text on Roman Britain. They tell visitors that, after they conquered England, Wales and some of Scotland, '[t] he Romans built towns, roads and villas. Latin became the official language and Roman law and money were introduced'. This brief description leaves little room for agency on the part of peoples native to the province, echoing Haverfield's one-sided model of Romanisation. The text goes on, however, to explain that '[a] Romano-British culture developed as new settlers from across the empire mixed with the local 
population'. This description resembles Frere's conception of Romanisation, for he argued that the culture of Roman Britain should be seen as a synthesis between Roman and Celtic elements. ${ }^{106}$ Nevertheless, it is also strongly reminiscent of the Roman-native dichotomy which has long dominated models of cultural change, not least because the text suggests that the 'Roman' characteristics of the Romano-British culture were brought about by outsiders ('new settlers') from other provinces who supposedly were already Romanised, while native populations took no active part in this.

The presence of 'foreigners' in Roman Britain is given special attention in the Roman Britain gallery. This has been a deliberate choice, for a document about the concepts which underlie the representation of Roman Britain in the British Museum's Weston Gallery explicitly mentions that the 'cosmopolitan nature of the Empire (multi-ethnic, multi-cultural, multi-lingual)' is brought to the fore in the gallery. ${ }^{107}$ An information panel titled 'Language and Literacy', for example, informs visitors that:

The Roman Empire united many different cultures and peoples through trade, military service or the administration of government. Even in the forts and towns of a distant province like Britain you might hear Greek, Hebrew, Palmyrene or Coptic spoken. Greeks, Jews, Syrians, Egyptians and north Africans could rub shoulders with Britons, Gauls and Germans.

The presence of people from other parts of the Empire is also foregrounded in labels which accompany the epigraphic material.

\section{The representation of the Roman military}

The Roman army is as prominent in the current display as it was during the previous century, with material attributed to soldiers flanking the central walkway in the northern half of the room; the prominence of the artefacts placed there is further enhanced on days with lots of sunlight when natural light floods into the room from a series of skylights located right above the central walkway. For reasons already outlined, this is unsurprising, because the museum's Romano-British collection contains a large collection of Roman militaria and much of the epigraphic material can be linked to men who served in the army. In addition, the material related to the military has only grown since the discovery of the first Vindolanda tablets in 1973, which, like later finds, were added to the museum's collection.

What is noteworthy, however, is that an information panel describing 'the role of the army in Britain' does not even consider the possibility of military repression. Instead, the army is presented as a benign and industrious presence, engaging in useful activities such as construction work, the building of roads and assisting in the administration of the province. In fact, (the possibility of) resistance to Roman rule is completely ignored, with only a single cursory mention of Boudica's rebellion on the label which accompanies the reconstruction of Classicianus' tomb: 'The Roman historian Tacitus tells us Classicianus was appointed procurator in A.D. 61, following the failed rebellion of Boudica, queen of the Iceni tribe of East Anglia. He appears to have been successful in restoring peace after the Romans had come near to defeat.' Although one should not go as far as to suggest that Roman rule was resented by the majority of people living in Britain even after the initial phase of brutal conquest, ${ }^{108}$ it would surely be worthwhile, for the sake of balance, to consider the possibility that the presence of Roman rule and the army could be experienced as repressive and, therefore, could have fostered resentment among some. The topic of repression and resistance is discussed in a book written by the

106 Frere 1967, 303.

107 Johns 1997/2000, 2, 4.

108 Mattingly $(2007,7)$ has argued that Roman rule was widely resented even in the medium and long term. 
curators responsible for the Romano-British collection, published in 2010 by the British Museum Press, ${ }^{109}$ so it may simply be a matter of time before this discussion is incorporated into the narrative presented in the Roman Britain gallery.

\section{The representation of Roman imperialism}

In similar fashion, the exploitative nature of Roman rule is hardly touched upon in the current exhibition. The Romans are credited with, among other things: the more widespread presence of literacy; encouraging trade and commerce by establishing a standard system of weights and measures; the introduction of better standards of hygiene and health and better medical treatment; enabling the large-scale production of iron objects; and, finally, the introduction of new building methods and techniques. Apart from the fact that at least some of these changes probably did little to improve the lives of the majority of the population, this description is largely accurate. However, the emphasis is strongly on what the Romans supposedly brought to the peoples native to Britain (again the likely role of native agency is largely ignored by the strong association between these changes and the advent of Roman rule); what they took in terms of taxes, resources and wealth is also not brought to the fore. The 2010 British Museum publication again gives reason to believe that it might only be a matter of time before this imbalance is addressed:

Much of the British landscape was managed and exploited by the Romans, and the majority of the rural population were engaged in food cultivation or craft activities. In fact, controlling land resources was in many ways the most important consideration of the Roman administration: areas with abundant mineral reserves were taken into state control and other land sequestered for army use, or for ex-soldiers, in the case of fields surrounding coloniae; and private landowners were taxed on their produce. ${ }^{110}$

Of course, there is a limit to the amount of nuance which can be built into a museum display, but it is possible to make the current exhibition somewhat more balanced in this respect.

\section{The representation of the (material) culture of Roman Britain}

Whereas the central walkway in the northern half of the Weston Gallery is flanked by objects relating to the Roman army, its southern half is flanked by some of the aesthetic highlights in the collection: the Corbridge lanx, the Hoxne hoard, the Thetford treasure, the Water Newton treasure, the Mildenhall treasure and the Ashwell hoard. Taken together, this collection of exquisite jewellery, sumptuous silver tableware and gold and silver coins convincingly gives the lie to the belief that the material culture of Roman Britain was inferior to that of regions nearer to the Mediterranean, which is one of the reasons why this material was given such a prominent place. ${ }^{111} \mathrm{In}$ addition, archaeology is given a much more prominent place within the current display. Whereas Smith's 1922 account relied heavily on Tacitus' Agricola, an information panel entitled 'Roman Britain the nature of the evidence' sagaciously explains to visitors that:

[W]ritten sources are very biased and incomplete. (...) Published accounts were invariably written from the Roman perspective, never from that of the native population. (...) Though archaeological evidence is also imperfect, it is very different from written history and tells us

109 Hobbs and Jackson 2010, 36-7, 47, 60-1.

110 Hobbs and Jackson 2010, 85.

111 Johns 1998, point number 7. 
more about ordinary people and everyday life. New archaeological discoveries and methods continue to emerge and add to the data, so that our picture of Roman Britain is a changing and evolving one.

With this in mind, one final aspect of the current display should be mentioned - its Roman/ élite bias, whereby the vast majority of the objects displayed in the gallery come from 'Roman' categories of site, such as cities, towns, villas and military installations. This is not due to any bias on the part of the people who are responsible for the current exhibition or, indeed, those who were responsible in the past; it is the result of the Romano-centric research bias which has long been present in Romano-British archaeology, caused at times by a subconscious identification with all things Roman. In addition, Roach Smith's collection forms the core of the British Museum's collection of Romano-British antiquities, which means that a significant number of the objects come from Roman London. ${ }^{112}$ As a consequence, the non-villa rural settlements, which were inhabited by 95 per cent of the population, are largely absent from the current display. The different nature of life in the countryside is acknowledged only once in the current display on an information panel entitled 'Buildings': 'Though most inhabitants of the province must have continued to live in modest traditional dwellings themselves, their perception of architecture and engineering would have been profoundly altered by the buildings they saw around them.' Whether or not this was the case - inhabitants of more isolated rural areas may never have witnessed substantial changes of this type - the existence of unique regional characteristics is a theme worth exploring. The current curators have acknowledged the diversity which existed in rural areas in their 2010 publication, something which, hopefully, will gradually find its way into future versions of the Roman Britain display. ${ }^{113}$

\section{THE ROMANO-BRITISH COLLECTIONS OF THE MUSEUM OF LONDON TODAY AND THE IMPACT OF POST-COLONIAL CRITICISM}

The Roman London gallery in the Museum of London is very different from the Weston Gallery in the British Museum. The latter has chosen to present its Romano-British collection in a rather traditional way ${ }^{114}$ — most of the smaller objects are displayed in glass cases and the use of reconstructions is limited to a model of Housesteads fort and several colourful two-dimensional images, some depicting reconstructed scenes. Following the results of several interviews conducted with visitors who had just visited the museum, the amount of illustrations was expanded during a gallery refurbishment which was completed in 2007 to make the gallery more interesting to children. ${ }^{115}$

The Museum of London, by contrast, has chosen to make frequent use of reconstructions alongside traditional case layouts, together with some multimedia applications. The best example of the former is the section with reconstructed Roman rooms, which has formed the central feature of the gallery since it opened in December 1976 (though this part of the exhibition has been altered over the course of time). The reconstruction most popular with visitors is without doubt the triclinium, with the Bucklesbury mosaic which was uncovered during construction work in 1869 (FIG. 6). This mosaic has always attracted attention; at the time of its discovery it attracted an impressive 33,000 visitors during the three days on which people could view it in situ at the excavation site. ${ }^{116}$

112 Johns 1997/2000, 2.

113 Hobbs and Jackson 2010, 112.

114 Johns 1997/2000, 5.

115 The Research Factor 2002, 2, 6, 11-12; Jackson 2007, 8.

116 Sheppard 1991, 22. 


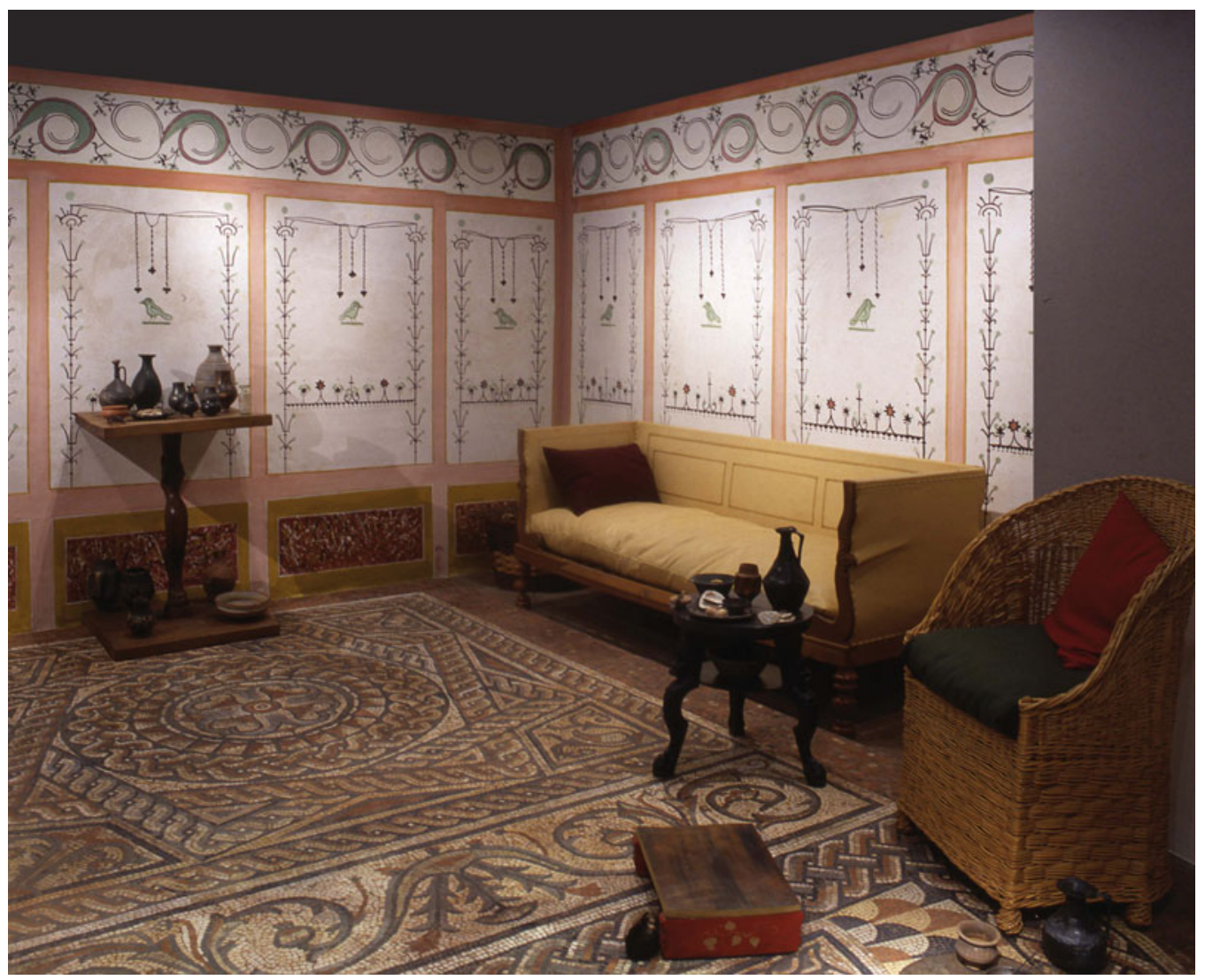

FIG. 6. Reconstructed Roman dining room in the Museum of London, photograph taken during the 2000s. (The Museum of London Picture Library (C) Museum of London)

\section{The representation of processes of cultural change}

Visitors enter the Roman London gallery via the prehistoric gallery (called 'London before London'), at the end of which a display of three glass cases introduces the Roman period under the heading 'A New Start?'. These cases are interesting from a post-colonial perspective, because they draw attention to the emergence of a hybrid culture after the Roman conquest. The text on the panel at the start of this display frames the decision as a choice between adapting to a new way of living or clinging to tradition as a generational issue:

Londinium was an ancient name that spoke soothingly of the great river - a small sop to wounded pride. For there were some who had forsworn the upstart foundation, some who preferred tribal ways. Others, younger perhaps and more adaptable, were happy to walk its freshly laid streets. For them, the great river that lapped at its feet told only of the future.

This rather simplistic explanation of cultural change is not very helpful. The text implies that older people were too stubborn to see that they were stuck in the past, clinging to 'tribal ways'. The term 'tribal' is unhelpful because it is laden with negative connotations of primitivism and cultural 
inferiority. ${ }^{117}$ In addition, the description ignores the fact that elderly people do not hold the monopoly on cultural conservatism and, moreover, creates the misleading impression that people had to choose between two opposites: assimilation or uncompromising conservatism. Fortunately, the content of the cases in this part of the gallery strongly suggests that there was a middle way - the construction, through a process of cultural negotiation, of new, hybrid, ways of life which combined the traditional with the new. The so-called 'Harper Road burial', displayed in one of the glass cases, provides a good case in point. The panel which offers some general background information on the burial informs visitors that:

In Londinium people combined new ideas and fashions with old customs, forging identities neither purely Roman nor purely British. A burial in Harper Road in Southwark reflects these changes and hints at a complex fusion of influences. The grave contained both imported and local items, and the method of burial was a mixture of old and new traditions too. (...) Hers [the buried woman's] was a new identity founded on the hopes, fears and beliefs of someone drawn to follow a new life in a new city.

From this introduction to Roman London in the prehistoric gallery, visitors proceed to the Roman London gallery itself. The gallery's arrangement is, in part, chronological — the first cases and the texts on the related panels tell of the Roman conquest, the construction of the first Roman settlement on, roughly, the location of the present-day City of London, Boudica's revolt, which laid waste to this settlement, and, finally, its subsequent rebuilding. Thereafter, the objects in the gallery are arranged thematically, focusing attention on topics such as trade, life in the Roman city and religion. Near the end of the gallery, a section with the evocative title 'Decline and Fall' (no doubt reminding a select few of Edward Gibbon's magisterial work) deals with the withdrawal of Roman authority from Britain and the decline of Londinium.

When compared with the Roman Britain gallery in the British Museum, the presence of 'foreigners' in Roman Britain is perhaps a little less accentuated in the Museum of London. Nevertheless, texts on information panels still draw attention to their presence. An information panel entitled 'Adopting and Adapting', for instance, makes clear that the 'social structure of Londinium reflected the complexity of the Roman Empire as a whole'. While the information panel, already mentioned, in the British Museum makes clear that incomers to Roman Britain came from as far afield as the Middle East and northern Africa, the 'Adopting and Adapting' panel in the Museum of London describes the inhabitants of London as a 'European community' which comprised people from 'Germany, France and Britain itself'.

\section{The representation of the Roman military and Roman imperialism}

As to be expected, the first part of the gallery draws attention to the role of soldiers in London. In keeping with Merrifield's description of this military presence, already quoted, an information panel entitled 'Raising Standards' offers a positive description of the military:

The Roman army was both defender and builder of Roman Britain. (...) Soldiers acted as military policemen, escorts for guard duties and as clerks in the civil service.

Elsewhere, on a panel entitled 'Public London', the c. 1,000 soldiers garrisoned in the Cripplegate fort are described as 'working in London as civil servants'. Again, as noted earlier, this description of soldiers as civil servants seems to be inspired by the contemporary experience of the role of soldiers in London. 
In contrast with the Roman gallery in the British Museum, however, an information panel entitled 'Chariots of Fire?' draws attention to Boudica's rebellion against 'Roman cruelty towards the Iceni and its royal family'. In addition, the text is critical of Tacitus' account of the rebellion, warning visitors that he may have exaggerated the amount of death and destruction it caused in order to achieve his own ends. Nevertheless, the possibility of military repression is not explored in any detail in the current display. Attention could, for example, have been drawn to the fact that the Iceni were evidently not the only people who had reasons to be hostile to Roman rule, since other peoples joined them in their rebellion against it.

\section{The representation of the (material) culture of Roman London}

The countryside is better represented in the Museum of London's Romano-British gallery than in its counterpart in the British Museum. An information panel entitled 'All roads lead to ... London' contains short sections on 'Road and riverside settlements' and 'Villas and farmsteads'. In addition, a case with objects associated with 'The food chain', contains some agricultural tools such as ploughshares, mattocks and sickles. Although the percentage of gallery space devoted to the countryside surrounding London is very small compared with that devoted to life in the city itself, this is a good start, especially since the relations between Roman London and its rural hinterland have only recently become the object of serious investigation. ${ }^{118}$

As mentioned above, reconstructions play an important part in the Roman London gallery. The series of reconstructed rooms - the dining room, a simple living room, another less elaborately decorated dining room and a kitchen - form the central feature of the gallery. Both the rooms and the associated furniture are reconstructions, but all the objects exhibited in the rooms were found during excavations in London. The objects are, therefore, in a manner of speaking, placed 'in situ', which helps visitors to bridge the gulf in time separating them from people living in the Roman period. Although, for instance, the reconstructed triclinium (FIG. 6) does not resemble modern dining rooms in any significant way (many recently built houses even lack a separate dining room), it still feels familiar, especially after one has just visited the prehistoric gallery. The same feeling of familiarity is created by a reconstructed Roman 'shopping street', which subtly evokes a marketplace feel. Similarly, in a video which is shown in the section of the gallery dealing with life in Roman London, a gladiatorial combat is presented using the format of a modern sports programme, the contestants being interviewed by a reporter both before and after the match has taken place.

These and other elements in the Roman London gallery create an image of the past opposite to that suggested by the much-quoted opening sentence from L.P. Hartley's novel The Go-Between: 'The past is a foreign country: they do things differently there.' 119 What might be less clear to visitors, however, is that they are encouraged to identify with a very specific and very small part of life and culture in Roman Britain, namely urban life and culture. On the one hand, it is hard to criticise the museum for this, for, after all, it is a gallery about Roman London. But on the other hand, it would be desirable to make clear to visitors that the gallery presents them with an image of the everyday life and surroundings of only a tiny fraction of Roman Britain's inhabitants.

\section{DISCUSSION}

As outlined in the introduction, late Victorian and Edwardian imperial concerns caused a Romano-centric research bias in Romano-British archaeology during the late nineteenth and the

118 Fulford 1998, 108; Cotton 2008, 61.

119 Hartley 1953, 9. 
early twentieth century. This bias led to one-sided theories of cultural change which over-emphasised the willingness of conquered peoples to adopt elements of Roman culture and ignored the possibility of the emergence of new hybrid cultural identities, resulting in unfounded images of cultural homogeneity. During the 1970s and 1980s, increasing theoretical debate and the introduction of post-colonial perspectives within Romano-British archaeology made archaeologists aware of this research bias and, since the 1980s, various solutions have been proposed to rectify it. This process is exemplified by the Romanisation debate, which has seen a move from simplistic images of one-sided processes of cultural change and consequent cultural homogeneity to complicated processes of cultural negotiation and cultural hybridity. In addition, the application of post-colonial theory to the study of Roman imperialism has enabled scholars to analyse the potential negative sides of Roman rule. This paper has attempted to shed some light on how the long-standing Romano-centric bias has - in combination with the experience of British imperialism - influenced past museum representations of Roman Britain and Roman London (in the British Museum and Museum of London, and its two predecessors, respectively). In addition, it has sought to establish to what extent post-colonial criticism has had an influence on the current representation of Roman Britain and Roman London in both museums. The most important findings are considered below.

An instructive point of contrast between the attitudes of some of the curators towards the antiquities in their collections is that the disparaging tone towards Romano-British works of art evident within Smith's 1922 guidebook is notably absent from the guidebooks published by the London Museum (most of them written by Wheeler) in the early twentieth century. Indeed, while Toynbee, as late as 1962, excluded the possibility that fine works of Roman period art found in Britain were produced there, Grimes would, six years later, maintain that the collection of sculptures found during the excavation of the Mithras temple 'as a whole can be claimed the equal of any so far recorded in the Western Roman Empire'. ${ }^{120}$ It is arguable that, for Smith it was the physical proximity of classical Roman art in other galleries of the British Museum which made him judge their Romano-British counterparts as inferior, while for Toynbee it was her firm background in classics which made her regard all high-quality works of art from Roman Britain as imports from either the Mediterranean or Gaul. The fact that both Wheeler and Grimes were more appreciative of the work of Romano-British craftsmen is most likely due to their experience as provincial Roman archaeologists. This probably enabled them to appreciate more readily the artistic creations of Romano-British craftsmen as works of art in their own right, without feeling the compulsion to compare these products with those made by craftsmen in regions closer to Rome.

The one-sided focus on Roman categories of site, in particular on urban sites - since the collections of both museums are strongly focused on London — is the most important shortcoming of the current permanent Romano-British galleries in both museums. As noted above, this is not the result of any bias on the part of the curators responsible for these galleries, even if such a focus might reasonably be expected in the Museum of London which focuses on the history of the modern city and its distant 'predecessors'. Instead, it is largely a consequence of a long-standing Romano-centric research bias within Romano-British archaeology. This bias is still present in the current museum representations of the Roman period in the British Museum and the Museum of London. It may not, however, be the only reason for the strong focus on urban (material) culture in both museums, which might also be caused by the longevity of a key aspect of Graeco-Roman discourse: the prominent role of the city and a belief in the superiority of urban culture. ${ }^{121}$ In addition, the dominance of cities today has made it almost impossible to imagine life at a time when most people lived outside

120 Grimes 1968, 106.

121 Grew 2001, 18. 
them. When people think of the Roman period, therefore, most will think of cities (or villas) with imposing stone structures, elaborately decorated residences, fine metal tableware, valuable jewellery, etc. All the while they forget that the vast majority of people of this period (and indeed of any historical period prior to the advent of the industrial revolution) did not live in such an environment, but in the countryside. Unintentionally, the representation of the Roman period in both museums perpetuates this image. This is regrettable since much archaeological work has recently been done in the countryside, a process which began in the late 1960s and accelerated during the $1990 \mathrm{~s}$, in no small part due to the contribution made by commercial archaeology; as a result more attention has been focused on non-villa rural settlements instead of villas and other Roman categories of site. Since museums form the public face of Roman and, indeed, all other forms of archaeology, it is desirable that the museum representations of Roman Britain and Roman London (including the latter's hinterland) change with these new directions taken by Romano-British archaeology.

Another key aspect of post-colonial criticism of Romano-British archaeology which has yet to find its way into the museum representations is a more critical analysis of the workings of Roman imperialism, which does not ignore its negative aspects. The topic of military repression, for instance, is explored in neither museum, while Boudica's rebellion against the Roman authorities is only cursorily mentioned in the Roman gallery of the British Museum. In addition, the Roman galleries of both museums make no mention of the exploitative nature of Roman imperialism. This is cause for concern because it leaves intact the premise that there is such a thing as 'benign imperialism', or, as the ancient historian Neville Morley has put it:

The image of the Roman Empire as the bringer of peace, order, prosperity and civilisation to the conquered provinces may be too well entrenched in Western culture for it to be able to support the criticism of imperialism in general, rather than criticism of the failures of a specific imperialism that falls short of Roman achievements. The example of Rome, it is implied, shows that not all interventions by a superior power are destructive or illegitimate; it offers an alibi for the admitted failures and atrocities of other empires, making the case that this time things can be different. ${ }^{122}$

No scholar who studies Roman imperialism will deny that the, often violent, introduction of Roman rule offered opportunities to some of the people living in the provinces, but equally, no scholar will support the idea that the Romans created their empire for, to borrow the words of Francis Haverfield, 'the betterment and happiness of the world'. ${ }^{123}$ Nevertheless, a similar, almost exclusively positive, evaluation of Roman imperialism remains embedded in the Roman galleries of both museums due to the absence of a balanced evaluation of its pros and cons.

It has also been noted that the current Romano-British galleries in both museums seek to highlight the presence of 'foreigners' (i.e. people from other parts of the Empire) in Roman Britain and, by extension, Roman London. It seems unlikely that this focus on incomers is due to the influence of post-colonial theory on studies of Roman Britain. For, although the last two decades have seen an increase in archaeological studies which focus on mobility and migration, in Roman archaeology the study of these themes has had a long and continuous history. ${ }^{124}$ One possibility is that the focus on 'foreigners' in the Romano-British galleries of both museums is mainly due to the influence of public and political debates about immigration (it gives the lie to the notion - expressed by some politicians on the far right — that immigration and multiculturalism are new phenomena without historical precedents). Its inclusion here is a reminder that scholarly debates are not the only factors which influence museum representations.

122 Morley 2010, 8-9.

123 Haverfield 1915, 10

124 Pearce 2010, 79 . 
The preceding pages have analysed the galleries with Romano-British antiquities in the British Museum and the Museum of London (and its two predecessors) from an academic perspective and, as such, have not been concerned with some of the wider issues faced by museum curators. In designing their galleries they are constantly faced by dilemmas, such as how to use the invariably limited amount of funds and available floor space and how to find a balance between a nuanced display representative of relevant scholarly literature and one which is accessible yet informative to members of the general public, most of whom, it bears reminding, will have little knowledge about Roman Britain or Roman London before they enter the museum. There are also aesthetic concerns which have to be taken into account. Several interviews conducted with visitors who had just visited the Weston Gallery of Roman Britain before its refurbishment in 2007, for example, revealed that a large number of visitors used the gallery as a walk-through to get to other galleries in the museum. ${ }^{125}$ It is hardly surprising, therefore, that the 'treasures' of Roman Britain are given such a prominent place, flanking the southern half of the central walkway in the Weston Gallery. The interview results show that more than half of the visitors (among them at least some of the people who had intended to use the gallery as a mere walk-through) stopped at the 'treasure exhibits'. ${ }^{126}$ Because of this, curators may be reluctant to devote a substantial part of the limited space in their gallery to the display of finds from non-villa rural settlements, as they are often less aesthetically pleasing than those found on urban or villa sites, despite being more representative of the material culture which was created and used by the majority of the population.

Many of the changes which are desirable from the point of view of post-colonial scholarship on Roman Britain can arguably be achieved without making significant changes to the make-up of the collections which are currently displayed in the Romano-British galleries of both museums. A more balanced representation of the Roman military, for example, will not be achieved by replacing some of the archaeological finds related to the military with other militaria, so much as by changing the interpretation of the military which is communicated to visitors through the texts on information panels. The same applies to the representation of Roman imperialism and processes of cultural change, which can be brought up to date by changing the way in which these processes (and the archaeological finds which are supposed to illustrate them) are represented in informative texts.

With regard to the one-sided focus on Roman categories of site, however, changes to the composition of the collections currently on display are desirable, particularly in respect of the inclusion of finds from rural settlements. Even here, however, much can be achieved by changes to the texts on information panels. Attention could, for example, be drawn to the regional diversity of rural settlement patterns, building styles and funerary practices, and also to the relative absence of Roman-style material culture in some rural areas. Unlike Roman galleries in local museums (which, like the Museum of London, naturally tend to focus on local archaeological finds) that in the British Museum displays finds from all over Roman Britain. Because of this, a representation of the regional diversity which existed in rural areas would be a valuable addition. It would make it clear to visitors that there was no homogeneous Romano-British culture and that, instead, regional diversity existed not only within the Roman Empire, but also within individual provinces like Britannia.

125 The Research Factor 2002, 2

126 The Research Factor 2002, 4. 


\section{CONCLUSION: CONTINUITY AND CHANGE}

The history of the representation of Roman Britain and Roman London in the British Museum and Museum of London (and its predecessors) respectively, is one of change and continuity. Elements which have not changed significantly over time are: the focus on Roman/élite categories of site and the almost exclusively positive representation of the Roman army and Roman imperialism. The former is arguably less of a problem in the Museum of London, since its aim to present the history of London will logically encourage such a focus. In spite of this, it is arguable that even the Museum of London's Roman gallery could be made more representative in this respect by devoting more attention to Roman London's hinterland. The representativeness of the British Museum's Roman Britain gallery would be much improved by including an impression of life in rural surroundings. The representation of the Roman army and Roman imperialism (in both museums) would benefit from the incorporation of a more nuanced, post-colonial, perspective. Both are still presented in overwhelmingly positive terms. From the point of view of education, it would be valuable if both museums offered an impression of the complexities of life under imperial rule, especially since this could contribute to visitors' understanding of how processes like imperialism and colonialism have shaped the world they live in.

The representation of the (material) culture of Roman Britain and processes of cultural change has changed over time. In the Roman Britain gallery of the British Museum this change can best be illustrated by the fact that the aesthetic highlights in the collection are now attributed to craftsmen from Roman Britain. In addition, their work is no longer described as inferior to that of craftsmen on the Continent, as was the case in Smith's 1922 guidebook. In the Roman London gallery of the Museum of London the change can best be illustrated by its nuanced depiction (on the information panel about the Harper Road burial) of cultural change as a process of cultural negotiation which resulted in the creation of new hybrid identities which were neither entirely Roman nor entirely British. This differs greatly from earlier Romano-centric models of cultural change. These changes demonstrate that the displays of the Romano-British collections in both museums have changed over time due to the influence of new, post-colonial, developments in Romano-British studies. It might be hoped, therefore, that both museums will continue to enrich their Romano-British displays with recent archaeological finds and insights, balancing the fine line between offering a display which is aesthetically pleasing and meets visitors' wishes and expectations, and one which offers new perspectives which challenge preconceived notions.

\section{ACKNOWLEDGEMENTS}

This paper results from an extracurricular research project I worked on during my MA studies. I am very grateful to the Radboud Honours Academy, which sponsored the project. Especial thanks are owed to Nathalie de Haan (Department of History, Radboud University Nijmegen), who has read, reread and commented on my numerous drafts, and Andrew Gardner (Institute of Archaeology, University College London), who read and commented on earlier versions of this paper. Their helpful comments have greatly improved the quality of my work. In addition, I would like to thank Francis Grew (senior curator of archaeology at the Museum of London) and Richard Hobbs (curator of the Romano-British collections at the British Museum) for kindly taking the time to answer some of my questions about the history of the Romano-British collections of their respective museums. I am also indebted to the two anonymous referees, whose helpful comments and suggestions saved me from a number of errors and have been of great help to improve the paper. Additional thanks are owed to Sally Brooks (librarian at the Museum of London Library) and Francesca Hillier (archivist at the British Museum Central Archive) for helping me find the relevant museum catalogues and guidebooks. Furthermore, I would like to thank Sarah Williams (picture researcher at the Museum of London Picture Library) and Iain Calderwood (editorial account 
manager at British Museum Images) for providing images of the current Romano-British galleries of their respective museums and for their help in sorting out all the copyright-related issues. I would also like to express my gratitude to the Roman Society for contributing to the costs of the reproduction fees for two of the images. Finally, I am grateful for the helpful criticisms and encouragement I received from my friends Maartje A.B. and Niels van de Weijer.

Roosendaal, The Netherlands

m.polm@hotmail.com

\section{BIBLIOGRAPHY}

Allen, G. 2014: 'Inflation: the value of the pound 1750-2002 - Commons Library Research Paper' (2nd edn). Accessed on 04-01-2016 via: http://www.parliament.uk/briefing-papers/RP03-82.pdf

Ayres, P. 1997: Classical Culture and the Idea of Rome in Eighteenth-century England, Cambridge

Bowden, M. 1991: Pitt Rivers: The Life and Archaeological Work of Lieutenant-General Augustus Henry Lane Fox Pitt Rivers, DCL, FRS, FSA, Cambridge

Brailsford, J.W. 1951: Guide to the Antiquities of Roman Britain, London

The British Museum: 'Floor plans and galleries'. Accessed on 04-01-2016 via: http://www.britishmuseum. org/visiting/floor_plans_and_galleries.aspx

Cotton, J. 2008: 'Landscape, environment and hinterland: introduction', in J. Clark, J. Cotton, J. Hall, R. Sherris and H. Swain (eds), Londinium and Beyond. Essays on Roman London and its Hinterland for Harvey Sheldon, York, 61

Darton, F.J.H. 1914: The London Museum, The Treasure-House Series, London

Dyson, S.L. 2006: In Pursuit of Ancient Pasts. A History of Classical Archaeology in the Nineteenth and Twentieth Centuries, New Haven, CT

Franks, A.W. 1869: 'British and Medieval Room', in J.W. Jones (ed.), A Guide to the Exhibition Rooms of the Departments of Natural History and Antiquities, London, 121-8

Franks, A.W. 1871: 'British and Medieval Room', in J.W. Jones (ed.), A Guide to the Exhibition Rooms of the Departments of Natural History and Antiquities, London, 124-9

Franks, A.W. 1877: 'British and Medieval Room', in J.W. Jones (ed.), A Guide to the Exhibition Rooms of the Departments of Natural History and Antiquities, London, 131-7

Freeman, P.W.M. 1996: 'British imperialism and the Roman Empire', in J. Webster and N. Cooper (eds), Roman Imperialism. Post-colonial Perspectives, Leicester, 19-34

Frere, S.S. 1967: Britannia: A History of Roman Britain, London

Fulford, M. 1998: 'Epilogue: a view of Roman London from the hinterland', in B. Watson (ed.), Roman London: Recent Archaeological Work, including Papers given at a Seminar held at The Museum of London on 16 November 1996, JRA Supplementary Series 24, Portsmouth, RI, 107-12

Fulford, M., and Holbrook, N. 2011: 'Assessing the contribution of commercial archaeology to the study of the Roman period in England, 1990-2004', Antiquaries Journal 91, 323-45

Gardner, A. 2013: 'Thinking about Roman imperialism: post-colonialism, globalisation and beyond?', Britannia 44, 1-25

Grew, F. 2000: 'Whose Londinium? Theirs or ours?', London Archaeologist 9, 161-6

Grew, F. 2001: 'Representing Londinium: the influence of colonial and post-colonial discourses', in G. Davies, A. Gardner and K. Lockyear (eds), TRAC 2000: Proceedings of the Tenth Annual Theoretical Roman Archaeology Conference, Oxford, 12-24

Grimes, W.F. 1968: The Excavation of Roman and Mediaeval London, London

Guildhall Museum 1908: Catalogue of the Collection of London Antiquities in the Guildhall Museum. Prepared under the Direction of the Library Committee of the Corporation of the City of London (2nd edn), London

Harden, D.B. 1960: The London Museum: An Illustrated Guide, London

Hartley, L.P. 1953: The Go-Between, London

Haverfield, F. 1915: The Romanization of Roman Britain (3rd edn), Oxford 
Hawkins, E. 1854: 'Notes of a remarkable collection of ornaments of the Roman period, connected with the worship of the Deae Matres, and recently purchased for the British Museum', Memoirs of the Archaeological Institute of Great Britain and Ireland, Oxford 1850, London

Hawkins, E. 1859: 'British and Medieval Room', in A. Panizzi (ed.), A Guide to the Exhibition Rooms of the Departments of Natural History and Antiquities, London, 98-102

Hingley, R. 2000: Roman Officers and English Gentlemen. The Imperial Origins of Roman Archaeology, London

Hingley, R. 2008: The Recovery of Roman Britain 1586-1906: A Colony so Fertile, Oxford

Hobbs, R., and Jackson, R. 2010: Roman Britain. Life at the Edge of Empire, London

Jackson, R. 2007: 'Treasure to tablet', British Museum Magazine, Winter 2007, 8

Jenkins, I. 1994: 'Classical antiquities', in A. MacGregor (ed.), Sir Hans Sloane. Collector, Scientist, Antiquary, Founding Father of the British Museum, London, 167-73

Johns, C. 1998: 'Comments on Robin Iles' review of Weston Gallery', The British Museum, Department of Prehistory and Europe Archive

Johns, C. 1997/2000: 'The Weston Gallery of Roman Britain. The rationale behind the display', The British Museum, Department of Prehistory and Europe Archive

Law, E. 1912: The London Museum at Kensington Palace: Being a Historical Guide to the Palace and its Contents, and likewise to the Orangery Museum-Annexe and Gardens, London

Mattingly, D.J. 2007: An Imperial Possession. Britain in the Roman Empire, 54 BC-AD 409, London

Mattingly, D.J. 2014: Imperialism, Power, and Identity. Experiencing the Roman Empire (2nd edn), Princeton, $\mathrm{NJ}$

Merrifield, R. 1978: A Handbook to Roman London, London

Morley, N. 2010: The Roman Empire. Roots of Imperialism, London

Museum of London 1976: The Museum of London Guide, London

Museum of London 1988: The Museum of London (2nd edn), London

Museum of London 1995: A Guide to the Museum of London, London

Netzer, N. 2014: 'Displaying Roman Britain in the British Museum', in L.R. Brody and G.L. Hoffman (eds), Roman in the Provinces. Art on the Periphery of Empire, Chestnut Hill, MA, 195-214

Pearce, J. 2010: 'Burial, identity and migration in the Roman world', in H. Eckardt (ed.), Roman Diasporas. Archaeological Approaches to Mobility and Diversity in the Roman Empire, Portsmouth, RI, 79-98

Potter, T.W. 1997: 'Later prehistory and Roman Britain: the formation of the national collections', in M. Caygill and J. Cherry (eds), A.W. Franks. Nineteenth-century Collecting and the British Museum, London, 130-5

Rogers, M. 1986: Blue Guide Museums and Galleries of London (2nd edn), London

Scheicher, E. 2005: 'De vorstelijke Kunst- en Wunderkammer', in E. Bergvelt, D.J. Meijers and M. Rijnders (eds), Kabinetten, galerijen en musea. Het verzamelen en presenteren van naturalia en kunst van 1500 tot heden, Zwolle, 15-42

Sheppard, F. 1991: The Treasury of London's Past. An Historical Account of the Museum of London and its Predecessors, the Guildhall Museum and the London Museum, London

Smith, R.A. 1922: A Guide to the Antiquities of Roman Britain in the Department of British and Mediaeval Antiquities, London

The Research Factor 2002: 'Gallery development: Celtic \& Roman Britain Galleries', The British Museum, Department of Prehistory and Europe Archive

Vaux, W.S.W. 1851: Handbook to the Antiquities of the British Museum: Being a Description of Greek, Assyrian, Egyptian, and Etruscan Art preserved there, London

Wheeler, R.E.M. 1926: Guide to the Roman Room, London

Wheeler, R.E.M. 1930: London in Roman Times, London Museum Catalogues: No. 3, London

Wheeler, R.E.M. 1955: Still Digging: Interleaves from an Antiquary's Notebook, London

Wilson, D.M. 2002: The British Museum. A History, London 